\title{
Tokiko garapena eta ekonomia sozial eraldatzaileko tokiko sistemak: Beterri-Buruntza-ko kasua
}

\author{
Local development and local systems of transformative social economy: \\ case study of Beterri-Buruntza
}

\author{
Andoni Egia Olaizola*
}

Tokiko garapeneko teknikaria, Hernaniko udala

Doktoregaia UPV/EHUn, HEGOA Institutuko Garapen Ikasketen Doktorego Programan

\begin{abstract}
Laburpena: Artikulu honen helburua da Ekonomia Sozial eta Eraldatzaileko Tokiko Sistemen (ESETS) sorkuntza eta sustapena tokiko-garapenerako eredu alternatibo gisa aurkeztea.

Horretarako, Gipuzkoako Beterri-Buruntza eskualdeko garapen ekonomikoaren planean 2013 urtetik 2020ra bitarte egindako proiektuak azaldu eta Ekonomia Sozial eta Eraldatzaileko Tokiko Sistema eraikitzeko estrategia integral baten barruan kokatuko dira. Estrategia horren bidez, lurraldean ekonomia sozial eta eraldatzaileko enpresak sortzeko, inkubatzeko, finkatzeko eta artikulatzeko dispositibo, espazio eta zerbitzuen multzoa eskaini nahi izan da, bai eta ESEko lurralde-ekosistema bat loratzeko ingurune egokia sortzea helburu zuten politika publikoak sustatzea bilatu da.

Ondorio gisara, Beterri-Buruntza eskualdean egin den tokiko garapenerako saiakera hau baloratzeko orduan bi dimentsiotan fijatu gara. Batetik, tokiko garapenenaren sustapenerako eredu alternatiboa gauzatzea lortu dela ebatzi da 4 arrazoietan oinarrituz. Bestetik, tokiko garapenerako eredu alternatibo honek BeterriBuruntzan ESETS baten oinarriak finkatu dituela baieztatzen da, nahiz eta ezin den baieztatu administrazio publikoaren bulkadarik gabe ESETS honek aurrera jarraituko duen.
\end{abstract}

Hitz gakoak: Tokiko Garapena; Tokiko Garapenerako Agentziak; Ekonomia Sozial eta Eraldatzaileko Tokiko Sistemak, ESE-ko Ekosistemak.

Abstract: The objective of this article is to present the creation and promotion of Local Systems of Social and Transformative Economy (LSSTE) as an alternative model of local development.

To do this, we will present the projects carried out between 2013 and 2020 at the Economic Development Plan of the Beterri-Buruntza, region of Gipuzkoa, and we will be framed within a comprehensive strategy for the construction of the Local System of Social and Transformative Economy. This strategy aims to offer a set of devices, spaces and services for the creation, incubation, consolidation and articulation of companies of social and transformative economy in the territory, as well as promote public policies that sought to create an environment conducive to the achievement of a territorial ecosystem of the SSE.

As a result, we have focused on two dimensions in assessing this attempt at local development in the Beterri-Buruntza region. On the one hand, it is resolved that an alternative model for promoting local development has been implemented on the basis of four reasons. On the other hand, it is confirmed that this alternative model for local development has laid the foundations of an LSSTE in Beterri-Buruntza, although it cannot be confirmed that this LSSTE will continue without the impetus of the public administration.

Keywords: Local development; Local development agencies; Local systems of social and transformative economy; SSE ecosystems.

* Harremanetan jartzeko/Corresponding author: Andoni Egia Olaizola. Tokiko garapeneko teknikaria. Hernaniko udala a-egia@hernani.eus

Nola aipatu/How to cite: Egia Olaizola, Andoni (2021). "Tokiko garapena eta ekonomia sozial eraldatzaileko tokiko sistemak: Beterri-Buruntza-ko kasua», GIZAEKOA - Revista Vasca de Economía Social, 18, 235-271. (https://doi.org/10.1387/gizaekoa.22900).

Jasoa: 2021/06/07; onartua: 2021/06/24.

ISSN 1698-7446 - elSSN 2444-3107 / (c) 2021 UPV/EHU 


\section{Sarrera}

Garapen ekonomikorako politika eta estrategiek eraldaketa handia bizi izan dute 1970. hamarkadan bizitako krisiaz geroztik, goitik beherako norantza zuten diseinu eta inplementazio estrategia zentralizatu eta bertikaletan oinarrituta egotetik, tokian-toki existitzen ziren baldintza eta aukerak identifikatu, sustatu eta aktibatzean oinarritu diren behetik gorako estrategia deszentralizatuetara pasatuz. Horrela, gobernu zentralek diseinatutako politika makroekonomikoak gauzatzean eta industrializazioa hauspotzea helburu zuten azpiegituretan oinarritzen ziren politikak nagusi izatetik, tokiko giza kapitala eta kapital soziala sustatu eta berrikuntza sozial, teknologiko eta produktiboa indartzen dituzten politikak jorratzera igaro dira, beti ere, nazioarteko kapital fluxuak erakartzeko eta nazioarteko merkatuetan kokatzeko helburuz.

Tokiko garapenerako literaturak sakonki aztertu eta teorizatu du politika ekonomiko bertikal eta zentralizatuetatik lurralde garapenerako politika horizontal eta deszentralizatuetara eman den trantsizio eta eraldaketa hau. Horrela bi ereduen arteko kontrakotasunak eta dibergentziak azpimarratzen dira. Batetik garapen exogenoa eragiten duten garapenerako poloen sustapena, eta bestetik, tokiko gaitasunak aktibatu eta tokiko agenteen partaidetzan oinarritzen diren garapen endogenorako proposamenak kontrajartzen dira (Alburqurque 2004; Vazquez-Barquero 2000; Böcker 2005). Artikulu honetan, bada, bi eredu hauen arteko balizko haustura baino, bi ereduen artean dagoen egiturazko jarraikortasuna azaleratuko dugu, biak ala biak kapitalaren metaketa eta mugarik gabeko hazkunde ekonomikoa helburu dituztela azpimarratuko dugularik.

Aipatu lurralde garapenerako eredu hauek baina, ezin izan dute egun bizi dugun egiturazko krisia ekidin, are eta gehiago, gure ustez eredu hauen hedapena izan da egun bizi dugun krisi sistemikoaren oinarrian aurki ditzakegun azalpen ugarien arteko bat.

Honen aurrean badira lehiakortasuna, hazkundea eta kapital metaketa helburu ez dituzten beste lurralde garapen eta ekonomia eredu batzuk, ekonomia sozial eta eraldatzailean oinarritzen diren enpresek eta egitura ekonomikoek aldarrikatu eta gauzatzen dituztenak, hain zuzen ere.

Ekonomia Sozial eta Eraldatzaileak azken hamarkadetan hazkunde nabaria izan duen arren, oraindik oso urriak dira eredu ekonomikoa hau oinarritzat hartu eta berau sistematizatu, antolatu eta lurraldearen matrize produktiboan nagusi bihurtzen saiatu diren lurralde garapenerako proposamenak.

Artikulu honetan bada, Ekonomia Sozial eta Eraldatzailean oinarritzen den egitura ekonomiko bat sortu eta artikulatzea helburu izan duen lurralde garapenerako proposamen bat aztertuko dugu. Zehazki, Beterri-Bu- 
runtza Eskualdean 2013tik 2020. urtera egin den saiakera azalduko dugu, zeinak helburu nagusien artean Ekonomia Sozial eta Eraldatzaileko Tokiko Sistema (ESETS) bat hauspotzea zuen. Horrela, artikulu honen helburuak dira batetik, Beterri-Buruntza eskualdean 2013-2020 urteetan zehar garatu den tokiko garapenerako prozesuak tokiko garapenerako eredu alternatibo bat eraikitzea lortu duen ala ez ebaztea, eta bestetik, tokiko garapenerako eredu alternatibo horrek eskualdean ESETS bat gauzatzea lortu den ala ez zehaztea.

Artikuluaren egilea aztertzen den tokiko garapenerako prozesuan diharduen langile-teknikaria den heinean erabili den metodologia behaketa parte-hartzailearen izan da nagusiki. Horrenbestez ikerlariaren posizioa dela eta lehen eskuko dokumentu-iturrienganako atzikipen osoa eduki du ikerketa guztian zehar, eta dokumentu hauek izan dira jarraian eskaintzen diren azalpenak oinarritzeko eta datuak lortzeko iturri nagusia.

Artikulu honek honako egitura du: 1. Sarrera.-2. Tokiko garapena globalizazioaren garaitan.-3. Tokiko garapena EAE-n eta Gipuzkoan.-4. Beterri-Buruntza Udalak: Tokiko garapena eta ESE. 4.1. Ekintzailetza. 4.1.1. Koopfabrika. 4.1.2. Iturola Elkarlan Sorgunea. 4.2. Laneratzea/Gizarteratzea. 4.3. Lehenengo sektorearen sustapena: Beterri $\mathrm{Km} 0.4 .4$. Enpresen eraldaketa: Erakide. 4.5. Lurraldearen eraldaketa. 4.5.1. Eraldaketa Nodoa. 4.5.2. Beterri Saretuz.-5. Beterri-Buruntza-ko ESETS-a.-6. Eztabaida eta ondorioak.

\section{Tokiko garapena globalizazioaren garaitan}

Jakina da azken hamarkadetan globalizazioa bezala ezagutzen dugun metaketa fase batean gaudela. Honek mundu mailako integrazio produktiboa ekarri du, lanaren eta ekoizpenaren nazioarteko banaketa berri eta aldakorra ezarri duelarik, eta, espazio bakoitzari funtzio produktibo zehatz batzuk egokitu dizkiolarik. Horrela bada, lurralde bakoitza nazioarteko ekoizpen kateen baitako katebegi ezberdin batean kokatuta dagoen arren, mundu mailan artikulatzen den merkatu integratu batek ezartzen ditu lurralde bakoitzaren garapenerako baldintzak.

Tokiko garapena lurraldeek globalizazioak eragindako ekonomiaren balizko desterritorializazioari erantzuteko jaio zen praktika eta teoria multzoa da, eta honen helburu nagusia da lurralde zehatz bat nazioarteko merkatu eta fluxu ekonomikoetan txertatuz hazkunde ekonomikoa eta kapitalaren metaketa jarraitua ahalbidetzea.

Lurralde zehatz bat nazioarteko merkatuetan txertatu eta fluxu ekonomikoak erakarriz hazkundea eta kapitalaren metaketa bilatzeko helburuarekin estrategia eta ekintza multzo ezberdinak probatu dira denboran eta 
espazioan zehar. Bigarren mundu gerraren ostean estatua zen garapen ekonomiko eta soziala sustatzen zuen agente nagusia. Estatu mailako plangintza zentralizatuaren, eta, esku-hartze ekonomikoaren bidez azpiegitura eta industria politikak ezartzen ziren lurraldean zehar. Espazioaren funtzionalizazioa, garapenerako poloak eta espezializazio produktiboak sustatzen ziren, beti ere, nazioarteko lan banaketan estatu horrek zuen kokapenaren arabera baldintzatuak zeuden politikak eginez, eta, estatu horrek zituen gaitasunak (politikoak, ekonomikoak, teknikoak, zientifikoak, jakintzarenak...) mobilizatuz.

80. hamarkadaren bueltan ordea, kontrairaultza neoliberala bezala ezagutzen den paradigma politiko-ekonomikoa hedatu zen, eta, nagusitu zen garapenaren teoria hegemonikoan estatua hazkundearen eta metaketaren etsaitzat jotzen hasi zen (Mohan eta Stokke, 2000). Kontrairaultza ideologiko hau ekonomiaren globalizazio prozesuaren sakontzearen bidez gauzatu zen, zeinak nazioarteko ekonomiaren bateratze eta integrazio prozesua azkartu eta hedatu zuen. Horrela mundu mailan artikulatzen ziren merkatuetan lehiatzeko gaitasuna bihurtu zen arrakasta ekonomikoaren giltzarri. Globalizazio prozesua eta ekonomiaren liberalizazio prozesua eskutik joan diren eta elkar elikatu diren prozesuak izan dira, enpresen arteko lehiaren joko zelaia ia mundu osora zabaldu delarik, eta ondorioz, ezein lurraldetan kokaturik dauden enpresen jarraikortasunerako aukerak mundu mailan osatzen diren balio kateetan txertatzeko duten gaitasunaren araberakoak dira, hau da, nazioarteko merkatuetan lehiakorrak izateko duten gaitasunaren araberakoak.

Larrearen (1999) hitzetan merkatuan lehiatzen duten enpresak tokiko ekoizpen sistema zehatz batetatik abiatzen dira, eta enpresa hauek tokiko ekoizpen sistema horren parte eta espresio dira, hauen lehiakortasuna baldintzatzen duelarik. Tokiko ekoizpen sistemak produktu edo zerbitzu zehatz baten ekoizpen eta merkaturatzera bideratutako antolaketa edo egituratze enpresarialak bezala ulertu daitezke (Rendón eta Forero, 2014), zeintzuek enpresa txiki eta ertainen ekoizpen prozesuaren faseak artikulatzen dituzten lehiaren bidezko elkarlana sustatuz, berrikuntza interaktiboko prozesuak eraginez eta kanpo-ekonomiak aprobetxatuz. Tokiko ekoizpen sistemen ikuspuntuak dinamika endogenoak hartzen ditu garapena azaltzeko aldagai nagusi bezala. Ikuspuntu honen arabera enpresen hazkunde ekonomikoa ez dago beraien arteko hurbiltasun geografikoaren mende soilik; garrantzi handia du, halaber, herritarren partaidetza-sentipenak, konfiantza sortzeko, elkar eragiteko eta lankidetzan aritzeko gaitasunak, hau da kapital sozialak, eta era berean, ekintza instituzionala nahitaezko beste elementu bat da arauak prestatzeko eta betearazteko duen gaitasun eta boterearen ondorioz (IICA, 2013). 1970 hamarkadan orokortu zen eredu fordistaren krisiari hobekien aurre egin zieten lurraldeak 
enpresa txikietan oinarritzen zen egitura ekonomikoa zuten lurraldeak izan ziren, zehazki prozesu produktibo edo sektore ekonomiko gutxi batzuetan zentratzen ziren enpresa txiki kopuru handien aglomerazioa zuten lurraldeak. Edonola ere tokiko ekoizpen sistema bat osatzeko ez da nahikoa sektore berean ari diren enpresa kopuru handia edukitzearekin, baizik eta hauen arteko harremana eta egituratzea ezinbestekoa da. Horrela, honako hauek dira tokiko ekoizpen sistema bat definitzen duten elementu nagusienetako batzuk:

\section{1. taula}

Tokiko Ekoizpen Sistemen ezaugarriak

Sektore beraren parte diren enpresa txiki askoren presentzia. Horietako askok produktu berdina ekoiztu ohi dute.

Enpresen arteko harremantze maila altua, harreman intrasektorialak, askotan azpikontratazioan oinarritzen diren harremanak direlarik.

Ekoizpen sistema nahiko egituratua egon ohi da, eta kultura tekniko profesional metatu bat dago zeinak egokitzapen prozesu jarraia bizi duen.

Eremu hauek eragin handia eduki ohi dute bai tokiko ekonomian zein tokiko jendartean

Administrazio publikoen esku-hartzea egon ohi da, eta tokiko politika ekonomiko bat abiarazteko aukerak egoten dira.

Tokiko eragile ekonomiko eta politikoak Tokiko Ekoizpen Sistema baten existentziaz jabetu ohi dira, eta hau mantentzeko, babesteko eta egonkortzeko beharraz koziente dira.

Iturria. Geuk egina.

Horrela, eta Alburquerque-ren (2004) hitzetan berariazko politika behar da tokiko ekoizpen sistema horiei, funtsean mikroenpresek eta enpresa txiki eta ertainek osatzen dituztenak, berrikuntza teknologikoko azpiegitura eta zerbitzu espezializatuetarako sarbidea emateko, enpresen sorkuntza eta dibertsifikazioa errazteko, aurrerapen teknikoa sustatzeko, eta horrela, hazkunde ekonomikoa eta enpleguaren sorrera lurralde guztietan zabaltzea ahalbidetzeko, beti ere, garapen endogenoa sustatzeko aitzakipean: «Garapen endogenoak aukera ematen du globalizazioa ezaugarritzen duen lehia handiko ingurune batean kapitala metatzearen mekanika azaltzeko. (...) ezagutzaren hedapena, produkzioaren antolaketa malgua, urbanizazio-ekonomiak eta erakunde-sarearen dentsitatea dira produktibitatea 
handitzea ahalbidetzen duten prozesuak (...) Garapen endogenoa ekintzarako interpretazio bat da, eta tokiko garapen-politikak prozesu horietan eragiten du, eta horrek aukera ematen die hiri eta eskualdeei globalizazioaren erronkei erantzuteko» (Vazquez-Barquero, 2000:1). Tokiko garapenak bada, enpresetaz gain lurraldean eragiteko helburua dauka, lehiakortasuna lortzeko gakoak enpresen inguruan biltzen diren faktore politiko, sozial, teknologiko eta instituzionaletan dagoela aldarrikatzen duelarik.

Globalizazioaren garaiotan lurraldea bihurtu da ustez desterritorializazioa zekarren ekonomia ereduan eragin eta fluxu ekonomikoak tokikotzeko giltzarri nagusia. Horrela hegemonikoak bihurtu diren tokiko garapenerako teoria eta praktikek lehiakortasuna sustatu eta ondorioz hazkundea, garapena eta ongizatea lortzeko lurraldea baliabide edo errekurtso nagusienetako bat izatera pasa dela baieztatzen dute. Horrela bada lurraldeak berezkoak dituen kualitate, potentzialitate eta gaitasunak identifikatzea eta aktibatzea da tokiko garapenaren zeregin nagusia. Lurraldearen kalitatea da beraz, beti ere ikuspegi hegemonikoaren arabera, teknologia bati kultura batekin gurutzatzea ahalbidetzen diona; enpresei ingurumari zehatz batekin topo egitea; merkatuari lehia elkarlanean bihurtzea; eta ekonomiari jendartea eta berau osatzen duten norbanakoen nahiak mobilizatzea (Larrea, 2003).

Motzean, hau da Tokiko Garapenaren korronte nagusien atzean dagoen paradigma nagusia. Korronte nagusi honek garapena eta ongizatea hazkunde ekonomikoarekin eta kapitalaren metaketa hedatuarekin lotzen ditu, eta, lehiakortasuna izango da bai hazkundea zein kapitalaren metaketa ahalbidetuko dituen gako nagusia. Toki garapeneko estrategiaren xedea, beraz, lurraldearen egitura sozioekonomikoa aldatzea da, lehiakortasun, enplegu eta bizi kalitate handiagoko estadioa lortzeko (Calvo eta Gonzalez, 2011).

\section{Tokiko garapena EAE-n eta Gipuzkoan}

Garapen ekonomikorako politika publikoak EAE-n bost maila administratiboren arabera banatzen dira. Mailarik altuenean Europar Batasuna dago. 2020ko Europako Lurralde-Agendan ezartzen duenaren arabera bere egiteke nagusitzat ditu lurralde-garapenerako orientazio estrategikoak eskaintzea lurralde-dimentsioa gobernantza-maila guztietan integratuz, eta, Europa 2020 Estrategia lurralde-kohesioaren printzipioen arabera aplikatzen dela bermatzea (Europar Batzordea, 2011). Larrea eta Karlsen-ek (2015) Aranguren et al. (2012) zitatzen diotenaren arabera «Espainiako gobernuak, funtsean, araugintzarako eginkizuna du; Eusko Jaurlaritzak, bestalde, autonomia-maila handia du industria-politika definitzeko, eta oso 
ezaguna da azken lau hamarkadetan izan duen industria-politikaren sendotasunagatik eta izaera proaktiboagatik. Probintzia-gobernuek (aldundiek) paper kritikoa betetzen dute, zergak biltzeaz arduratzen direlako eta eskumenak dituztelako berrikuntza-politikei dagokienez. Azkenik, udal agintariek eskualdeko garapen-agentzien bidez goiko mailetatik ezartzen diren politikak tokian-tokiko azken onuradunengana bideratzeko ahalmena dute».

EAE-ri dagokionez, 1980. hamarkadan hasten da aplikatzen Lehiakortasunaren Euskal Estrategia ${ }^{1}$. Horrela, $\mathrm{I}+\mathrm{G}+\mathrm{B}$ azpiegituretan inbertitu zen hamarkada horretan eman zen berregituraketa industrialaren ${ }^{2}$ eta krisi ekonomikoaren aurrean eskainitako erantzun gisa. 1990.hamarkadan kluster politikak $^{3}$, eta, eraginkortasunean oinarritutako lehiakortasun ikuspegia eta negozioen ingurumaria hobetzeko politika proaktiboak ezarri ziren, eta, 2000 urtetik aurrera espezializazio adimentsua ezartzeko estrategiaren oinarriak finkatu ziren (Aranguren, Morgan, Wilson, 2016).

Estrategia hau izan da EAE-ko lurraldearen eta eskualdeen berrikuntzarako eta espezializaziorako estrategien aterki orokorra. Estrategia honek lurraldearen lehiakortasuna sustatzeko metodologia nagusitzat eduki du tokiko ekoizpen sistemak identifikatu eta sustatzea, hau da, lurralde mailan aglomerazioa eskaintzen duten enpresa-tipoen arteko elkarlanerako esparruak sortu eta dinamizatzea. Horrela, Becattini-k, A.Marshall-en kanpoekonomia kontzeptua garatuz proposatu zuen Distritu Industrialen sustapena bilatu da, hau da, enpresa txikien nagusitasunean; hauen arteko lankidetza estuaren sustapenean; diru-sarreren murrizketaren ordez konpetentziaren bidezko leihakortasuna sustatzean; enplegatzaile eta langile kualifikatuen arteko konfiantza handian, eta, berrikuntza errazten duten tokiko zein lurraldeko gobernu aktiboen jardunean oinarritzen zen espezializazio territoriala sustatu da Euskal Autonomi Erkidegoan, eta bereziki Gipuzkoako Lurralde Historikoan (Larrea, 2004).

Tokiko Garapen Agentziak dira garapen ekonomikoan eragina duten maila administratiboetan azkena, eta lehen aipatu bezala, goitik datozen gi-

${ }^{1}$ Eusko Jaurlaritzak, Industria Sailaren bidez, abian jarri zuen lehiakortasun-politika eta -estrategien multzoa.

${ }^{2}$ Ekoizpenerako eredu fordistaren krisiak eragin zuen mundu mailako berrantolaketa produktiboa. Ordura arte industria-ekoizpenaren gune nagusiak zirenak krisian sartu ziren eta industria askoren itxiera prozesuak gertatu ziren, espazio hauek tertziarizazio prozesuak bizi izan zituztelarik. Honen adibide garbi bat Bilbon bizitakoa da 70. harmarkadaren bigarren erditik aurrera.

${ }^{3}$ Geografikoki gertu dauden eta jarduera esparru bera edo konplementarioa duten enpresen eta erakundeen arteko elkar-harremana eta artikulazioa sustatzen duten lurralde garapenerako politiken multzoa. 
dalerroak lurraldean aplikatu eta eragile sozioekonomikotara bideratzeko zeregina dute besteak beste.

Tokiko Garapen Agentziak udal zein mankomunitateen jabetza diren erakunde publikoak dira eta beraien helburua da tokiko ekonomia eta enplegua sustatzea, hau da, tokiko garapenerako planak diseinatzea, ezartzea eta dinamizatzea.

Garapen agentziak 80.hamarkadako berregituraketa industrialak sortu zuen krisiari aurre egiteko lanabes gisa jaio ziren, eta hasiera batean tokiko enplegu-planak sustatzea zuten eginkizun nagusitzat. Hasiera batean berregituraketa industrialak modu gogorrenean jo zuen eskualdeetan sortu ziren arren, belaunaldi berriak etorri dira hamarkadak aldatu hala, eta, gutxinaka-gutxinaka Gipuzkoako eskualde guztietan zehar hedatu dira. Belaunaldi berriak etortzearekin batera beraien zeregin eta helburuak aldatzen joan dira, hasiera batean enpleguaren sustapena bazuten zeregin nagusi eta ia bakartzat, egun, funtzio eta eragin esparru berriak jorratzera pasa dira, hala nola, ekintzailetza, enpresen lehiakortasuna, nazioartekotzea, garapen teknologikoa eta lurraldeen espezializazio produktiboa sustatu eta indartzera igaro direlarik.

Tokiko garapenerako eredu hegemonikoa sustatzen duten agentziek lurraldearen lehiakortasuna handitzea dute helburu nagusitzat eta horretarako enpresen arteko sareak, klusterrak, eta distritu industrialak identifikatzean eta sustatzean oinarritzen dute euren lanaren zati handi bat. Hau dela eta, Gipuzkoako tokiko garapen agentziek, nahiz eta ez denak izan, kokatzen diren eskualdean nagusi den tokiko ekoizpen sistemaren arabera antolatzen dira, beraien jardunik garrantzitsuena ekoizpen sistema horren sustapena egin eta lehiakortasuna handitzeko zerbitzuak, proiektuak, baliabideak eta harreman sarea eskaintzea delarik (Larrea, 2003).

Gobernantzari dagokionez aipatzekoa da Gipuzkoan lurralde mailako gobernantza eredu kooperatibo bat sortzeko egiten ari den saiakera, Gipuzkoa Sarean deritzona. 2009. urtetik Gipuzkoako Foru Aldundia lurralde garapenerako gobernantza eredu propio eta kooperatibo bat ari da eraikitzen, zeinetan eskualdeetako garapen agentzietako teknikari, zuzendari eta lehendakariek, unibertsitateko ikertzaileek eta aldundiko politikariek hartzen duten parte. Prozesuaren helburua da lurraldearen lehiakortasuna handitzea bertako kapital soziala sustatzearen bidez, eta horretarako lurralde garapenerako ikerketa-ekintza metodologia propio bat sortu da. Metodologia hau "policy maker»-ak, ikerlariak eta garapen agentzietako zuzendari eta teknikariak barnebiltzen dituzten formakuntzarako, gogoetarako, eta elkar-ekintzarako espazioak edo «agorak» sortzean eta dinamizatzean oinarritzen da. Besteak beste espazio edo "agora» hauetan Aldundiak lurralde garapenerako eskaintzen dituen diru-laguntza batzuen nondik-norakoa ezarri da garapen agentzietako zuzendari eta lehendakarien esku-hartze zuenaren bi- 
dez. Aldundiaren azken helburua da Gipuzkoa mailan entseatzen ari den gobernantza kooperatiboko eredu hau eskualde guztietara hedatzea garapen agentzien lidergoaren bidez. Modu honetara lurralde-garapenerako gobernantza kooperatiboaren kapilarizazio prozesu bat eragin nahi da lurralde historikoaren garapenerako eredu koherente eta artikulatu bat eraikitzeko, beti ere, lurraldearen lehiakortasuna handitzeko helburu esplizituarekin (Larrea, 2019). Gipuzkoan sustatzen ari den gobernantza kooperatiborako proposamen hau da tokiko garapenerako teoria hegemonikoek bizi izan duten metamorfosiaren erakusgarri argi bat. Metamorfosi honek erakusten du nola garapenerako politikek norabide bertikaletatik, erabakigune zentralizatuetatik eta kapital fisikoaren ezarpenetatik, horizontaltasunera, deszentralizaziora eta kapital sozial eta erlazionalaren sustapenera egin duten salto. Metamorfosi hau baina ez da koiunturarekiko egokitzapen prozesu bat baino izan, zeinetan garapenerako politiken forma aldatu bada ere, muina eta helburua berak izaten darraien, hau da, enpresen eta lurraldearen lehiakortasunerako baldintza territorial, instituzional, sozial eta politikoak ezartzea hazkunde ekonomikoa eta kapitalaren metaketa ahalbidetzeko estrategia gisa, hau da, eredu kapitalistan sakontzeko estrategia gisa.

Horrela bada, eskala guztiak aintzat hartu eta hauen arabera antolatzen den garapen eredua sustatu da bai EAE-n zein Gipuzkoan, zeinak lurraldearen espezializazio adimentsua bilatzen duen tokiko gaitasun produktiboak saretuz eta hauek nazioarteko balio kateetan txertatuz. Tokiko eskalaren eta eskala globalaren kateatzeak tokiko ekonomiak indar eta eragile globalenganako neurrigabeko esposizio batetara bideratzen ditu, eta honek, hauetako eskualde batzuen garapen dinamikorako aukerak handitzen dituen bitartean, gehiengoaren ahultze orokortua eragiten du (Zurbano, Bidaurrazaga, Gainza, 2014). Gurean garapen dinamikoa edo ahultze orokortua eman den etorkizuneko eztabaidetan ebatziko da, baino baieztatu dezakeguna da jarraian azaltzen diren ondorioak eragin dituela EAE-n eta Gipuzkoan aplikatu den garapen ekonomikorako ereduak:

1. Tokiko eremuan kokatzen diren enpresen ekoizpena mundu mailako lehiak ezartzen dituen parametroetara (kalitatean, prezioan, kopuruan...) egokitu behar izan da, nahiz eta enpresa hauen merkatua eta eragin gunea tokiko eskalan kokatu, merkatuak ezartzen dituen baldintzak mundu mailan ematen den lehia honek determinatzen du. Honek garapen eredu extrabertitu bat eragin du, tokiko baldintzen arabera baino, kanpoko baldintzen arabera gauzatu den egitura ekonomiko bat eraginez, eta ondorioz, eredu hauen arrakasta nazioartean ebatzi diren faktoreen menpe gelditu da, eskualde batzuen dinamismoa handitu den bitartean beste batzuen gainbehera eman delarik. 
2. Gure lurraldean kokatzen diren enpresa hauek mundu mailan lehiatzen diren beste enpresengatik xurgatuak izateko arriskua gero eta handiagoa da, eta prozesu hau gero eta ohikoagoa da gure egunerokoan ${ }^{4}$. Honek eragina dauka gure lurraldeen garapenaren nondik norakoa ezartzeko orduan.

Batetik xurgatuak diren enpresa hauek produkzio kostuak merkeagoak diren beste lurralde batzuetara deslokalizatzen direlako, eta bestetik, askotan enpresa hauek itxi eta bertako ekoizpen gaitasuna desegituratu egiten delako. Horrenbestez jarraian azalduko dugun Beterri-Buruntza eskualdean enpresa hauen errotzea bilatu da, eta horretarako, deslokaezinak diren oinarriak (pertsonak) bihurtu nahi izan dira errotze horren subjektu eta protagonista. Lurraldearentzat ere, enpresa-eredu parte-hartzaileak lurralde-kohesioa eta enpresa-sarearen sendotasuna bultzatzen ditu, eta deslokalizazioarriskuaren aurrean antidotoa da (Bengoetxea, 2015). Horretarako ezinbestekoa da enpresen erdigunean pertsonak kokatzea, eta "partaidetza bultzatzen duten ahalik eta enpresa gehien izatearen aldeko apustua egitea, enpresa horietan lehiakortasunaren elementu bereizgarria baitira errenta-banaketa egokia, proiektu partekatu eta jasangarrien konfigurazioa, kalitatezko enplegua, ardura pertsona guztien artean banatzea, eta ingurunearekiko konpromezua» ${ }^{5}$ sustatzea.

3. Lanaren eta ekoizpenaren nazioarteko banaketa berri eta aldakorrak lurraldeetan eragiten duen espezializazio produktiboak askotan monofuntzionalitatea eragiten du, lurraldearen beharren eta ekoizpen gaitasunen arteko desaklope nabari bat eman daitekelarik, eta honek eragin handia duelarik lurraldeon erresilientzia gaitasunean. Desakople hau ez da nabaria espezializazio hori eraginkorra den bitartean, baino esan bezala, nazioarteko ekoizpen prozesuek bizi duten etengabeko aldaketak eragiten hasi eta espezializazio hori krisian sartzen denean, lurraldeak ez ditu bere beharrak asetzeko ez gaitasun ez eta konpetentzia produktiborik, krisiari aurre egiteko inolako baliabiderik gabe geldituz, eta, lurraldeen erresilientzia gaitasuna galduz. Horrela bada, jarraian azalduko dugun Beterri-Buruntzako ereduan lurraldearen espezializazioa baino, lurraldearen dibertsifikazio produktiboa sustatu da, beti ere, bizitzaren heda-

4 https://www.diariovasco.com/economia/empresas/huelga-ingemar-usurbil20190316191152-nt.html?ref=https:\%2F\%2Fwww.google.com\%2F

5 Gipuzkoako Foru Aldundiaren Ekonomia Sustapenerako, Landa Ingurunerako eta Lurralde Orekarako sailaren «Gipuzkoan, enpresetan pertsonen partaidetza sustatzeko programen diru laguntzen 2019ko deialdia». 
pena ahalbidetzen duten sektore estrategikoetan indarra jarriz, eta, lurraldearen eta jendartearen beharrak lurraldearen gaitasunekin berrakoplatzeko saiakera eginez.

\section{Beterri-buruntza udalak: tokiko garapena eta ESE-a}

Beterri-Buruntza Urnieta, Andoain, Usurbil, Lasarte-Oria, Astigarraga eta Hernaniko udalerriez osatuta dagoen eskualdea da eta 2012. urterarte ez du eduki eskualde mailako inolako egituraketarik (Sustapen ekonomikoari dagokionez). 2012. urtean sei herrien arteko 1go lankidetza hitzarmena sinatu zuten Enplegua eta Garapen Ekonomikoaren Sustapenerako, eta hortik aurrera Gipuzkoako Foru Aldundiaren Sustapen Ekonomikorako sailak eta Lanbidek Tokiko Enplegu Ekintzen bidez eskaintzen dituzten diru laguntzak jasotzen hasi zen. 2013an aipatu hitzarmen honen bidez Gipuzkoako Foru Aldundiaren Gipuzkoa Sarean prozesuaren baitako diru laguntza bat jaso zuen eskualdearen garapenerako estrategia eta erakundetze eredua diseinatuko zuen teknikari baten kontratazioa egiteko. Alkatetzan zeuden alderdien arteko desadostasunak medio baina, ez zen teknikariak proposatu zuen erakundetze eredua (S.A publikoa izango zen Garapen Agentzia bat) onartu, eta ondorioz, Enplegua eta Garapen Ekonomikoaren Sustapenerako hitzarmen hori izan zen 2020.urteraino sustatu den garapen ereduaren aterki juridikoa. 2020an mankomunizazioa onartu zuten eskualdea osatzen duten herrietan, eta honekin batera, bertan behera gelditu ziren hitzarmenaren baitan aurrera eraman ziren proiektu eta estrategiak, eta hauekin ESETS-a tokiko garapenerako eredua bihurtzeko ahalegina.

Esan bezala Beterri-Buruntza Udalak-ek udalaz gaindiko eremuan jardun arren, esparru hori ez da argi zehaztutako espazio sozioekonomiko bat, eta ez da egon horretarako eratutako erakunderik 2020. urterarte. Esan beharra dago, eskualde bezala errekonozitua ez egoteak Donostialdea makroeskualdearen baitan kokatuta egotea ekarri duela, eta ondorioz, berariazko estrategia ekonomikorik gabe, eta hiriburuak eragiten duen indar zentripetuaren ondorioz Donostiaren dinamika metropolitanoen menpe garatu da, egitura ekonomiko marshalliano difuso bat eratuz, eta espezializazio produktibo zehatz bat ekidinez. Honek determinantea den eragina izan du 2013. urtetik aurrera entseatu den garapen eredua zehazteko orduan, zer batean baino, hau da, espezializazio produktibo zehatz batzuetan baino, nola batean sakontzeko aukera eta beharra eskaini baitu, hau da, Ekonomia Sozial Eraldatzaileko Tokiko Sistema bat sustatzeko parada eskaini du. Morandeira eta Arcosen (2020) arabera ESETS-ek honako ezaugarriak betetzen dituzte: 


\section{2. taula}

ESETS-en ezaugarriak

Hurbiltasun fisikoak informazio-trukea, lankidetza, kultura eta ikaskuntza kolektiboa bultzatzen ditu eragile ekonomikoen, gizarte zibilaren eta administrazioen artean.

Loturak: ESS, tokiko garapena eta lurraldea berritzeko prozesuak.

Lurralde-agendatik abiatuta, enpresen arteko lankidetza bultzatzen duten espazioak, ekonomia-, gizarte- eta lurralde-mailako eraldaketarako.

Administrazio publikoek, enpresek eta gizarte- eta elkarte-sareak garatzen dituzten ekintzak, ekimenak eta estrategiak hitzartu, erlazionatu eta koordinatzea.

Berrikuntza, jasangarritasuna, ekitatea eta gizarteratzea.

Iturria. Morandeira eta Arcos (2020).

Garapenerako eredu hegemoniko kapitalistaren krisi multidimentsionalaren ebidentziaren aurrean (Fernández, 2016) Beterri-Buruntza eskualdean Ekonomia Sozial eta Eraldatzaileko Tokiko Sistema bat sortzeko saiakera egin da, hau da tokiko garapenaren literaturan hain ezaguna den eta lehenago azaldu dugun Tokiko Ekoizpen Sistemaren teoria eta praktika bereganatu, eta Ekonomia Sozial eta Eraldatzaileak eskaintzen duen ereduaren, helburuen eta praktiken arabera berformulatzeko saiakera egin da. Horrela, enpresa eta eragile sozioekonomikoak produktu edo zerbitzu baten arabera antolatu edo egituratu ordez, administrazio publikoak, eragile ekonomiko eta sozialak eredu baten sustapenerako, hau da ESE-a sustapenerako antolatu eta egituratu dira. ESETS-a horrela definitu genezakela proposatzen dugu: Ekonomia Sozial Eraldatzailea tokian-toki sustatu, hedatu eta lurraldeko matrize produktiboaren erdigunean jartzeko helburuarekin eskala zehatz batean estrategikoki artikulatzen eta egituratzen diren erakunde publiko, ekonomiko eta sozialen arteko gobernantza eredua, eta, gobernantza eredu honen baitan diseinatzen eta gauzatzen diren zerbitzu, proiektu eta prozesuak. Berriz ere Rendón eta Foreroren (2014) hitzak hartuz, »Tokiko Ekoizpen Sistemak tokiko garapenaren dimentsio produktiboaren baitan eratzen dira, eta honek ekoizpenerako harreman sozialak gauzatzea ahalbideratzen du». Hitz hauek gurera ekarriz bada, esan dezakegu Beterri-Buruntza eskualdean sustatu den ESETS-aren azken helburua izan dela ekoizpenerako harreman sozialak kapitalismoaren paradigmatik haratago gauzatzea.

Beterri-Buruntza eskualdean entseatu den eredua kontestualizatzeko ezinbestekoa da batetik gorago aipatu den Garapen Agentzien sortze prozesuan eman ziren belaunaldien arteko desberdintasunak ulertzea, eta bestetik, ESE-ak Euskal Herrian bizi izan dituen belaunaldi eta olatu ezberdinak kontutan hartzea. 
Horrela bada batetik, Gipuzkoa mailan sortu zen azkeneneko garapenerako estrategia izanik gorago aipatu diren garapenerako ikuspuntu berri eta berritzaileenekin egin zuen bat eskualdean proposatu zen ereduak. Eredu hau enplegua sustatzeaz gain lurraldeko kapital soziala eta honen berrikuntza interaktiborako gaitasuna handitzean oinarritu zen, beti ere, administrazio publikoa, ehun ekonomikoa, ehun soziala eta formakuntza eta jakintza zentroak barnebiltzen zituen foro iraunkorrak eta gobernantza esparru berriak sortuz. (Gainza eta Unceta, 2011). Horrela bada tokiko garapenerako eredu alternatibo honek Quebec-en 1990. hamarkadatik aurrera garatu den (Etxezarreta, Etxezarreta, Zurbano, Estensoro, 2015) eredua dauka aitzindari eta eredutzat, zeinak lurraldearen egitura ekonomikoaren eraldaketa bilatzen duen eragile sozio-ekonomiko nagusienen arteko gobernantza publiko-kooperatibo-komunitario eredu propio batzuen bidez.

Bestetik, Beterri-Buruntza eskualdean ESE-an oinarritzen den garapenerako estrategia berri, eta Gipuzkoan behintzat bakarra jarri da martxan. Estrategia honek helburu nagusitzat eduki du jasangarritasuna, parekidetasuna, inklusioa eta demokrazia ekonomikoa ardatz izango dituen eredu sozioekonomiko berri bat sustatu, egonkortu eta hedatzea. RIPESS ${ }^{6}$-en arabera «Ekonomia sozial solidarioa garapen ekonomikoari ekiteko modu bat $\mathrm{da}$, eta herrien eta planetaren ongizateari ematen dio lehentasuna irabazien eta garapen itsuaren gainetik». Definizio hau honako moduan sakontzen du «Ekonomia sozial solidarioa (ESS) kapitalismoaren eta Estatuak kontrolatzen dituen sistema ekonomiko autoritarioen alternatiba da. (...) ESS ekonomiaren sektore guztietan dago: ekoizpena, finantzak, banaketa, trukea, kontsumoa eta gobernantza. ESS-ak sistema sozial eta ekonomikoa eraldatu nahi du, sektore publiko eta pribatuak eta hirugarren sektorea barne. ESSaren helburua ez da soilik pobrezia murriztea, baita gizarte-klase guztiak barne hartzen dituzten desberdintasunak gainditzea ere. Gaur egungo sistemaren praktika onenak (eraginkortasuna, teknologiaren erabilera eta ezagutza) erabiltzeko eta komunitatearen onurarako bideratzeko gaitasuna du ESS-aren mugimenduaren balio eta helburuen arabera» ${ }^{7}$. Ekonomia Sozial eta Eraldatzailearen 3 belaunaldi bereizi ditzakegu: 1goa Kooperatibagintza klasikoaren hedapen eta kontsolidazio fasea 1960-80 hamarkaden artean emandakoa; 2.a Ekonomia Solidarioaren agerpena $\mathrm{REAS}^{8}$-en bueltan eta ikuspegi post-kapitalista zuena 1990. hamarkadan, eta, 3.a krisi garaian garatu zen ikuspegi berria: territorializatua, eraldatzailea eta modalitate anitzak barnebiltzen zituena. Azken belaunaldi honetan Euskal Herriko Ekonomia

${ }^{6}$ RIPESS ekonomia sozial eta solidarioa sustatzeko konpromisoa duten sare kontinentalen munduko sarea da

7 http://www.ripess.org/que-es-la-ess/es-economia-social-solidaria/?lang=es

8 REAS Ekonomia Alternatibo eta Solidarioaren sareen Sarea da. 
Sozial eta Eraldatzailearen Olatukoop sarea sortu zen 2014. urtean (Villalva-Eguiluz et al., 2019). Ikusi daitekenez Beterri-Buruntza eskualdeko garapen prozesuaren hasierak bat egiten du aipatu 3 belaunaldien azkeneko belaunaldiarekin, lurraldea zentroan jarri eta tokian tokiko garapen eredu berriak proposatzen dituen belaunaldiarekin, hain zuzen ere.

Kooperatiba da Ekonomia Sozial eta Eraldatzailearen enpresa eredu nagusia eta enpresa eredu honen erreferente nagusiena den $\mathrm{ACI}^{9}$-aren 5. 6. eta 7. printzipioek bat egiten dute zeharo tokiko garapenaren ikuspegi aurreratu eta berritzaileenekin ${ }^{10}$. Horrela, enpresa kooperatiboak tokiko garapenerako agente nagusi dira bi arrazoi nagusirengatik: batetik ekonomia sozialeko enpresak tokiko komunitateek beraien beharrak asetzeko sustatzen dituzten estrategien ondorio direlako, eta bestetik, eremu jakin batean dauden baliabideak eraginkortasunez aprobetxatzen dituztelako ekonomia dinamizatuz, enplegua sortuz eta populazioaren bizi-baldintzak hobetuz (Calvo eta Gonzalez, 2011).

Ingurumari honetan ulertu behar da Beterri-Buruntza eskualdean entseatu den garapenerako estrategia. Estrategia honek, arestian aipatu den tokiko garapenerako paradigma nagusia ezbaian jartzen du, hau da, lurraldearen lehiakortasuna sustatzea dela tokiko garapenaren zeregina hazkunde ekonomikoa eta ondorioz ongizatea lortzeko. Mugarik gabeko hazkunde ekonomikoa da egun bizi ditugun krisi ekonomiko, anbiental, sozial eta politikoaren arrazoien artean nagusienetakoa (Perez Orozco, 2014) eta ondorioz, printzipio hauetan oinarritzen den tokiko garapenerako paradigma hegemonikoa da, lurralde gehienetan aplikatu dena, krisi hauen intentsifikazioaren eta hedapen espazialaren arrazoia.

Horrela, Beterri-Buruntzan garatu den saiakerak jendarte guztiaren beharrak asebetetzeaz gain, aipatu krisi sistemikoari tokian-tokiko erantzun eraldatzaileak eskaini nahi izan dizkio. Eredu hau Giza Garapen Jasangarriaren markoan kokatu daiteke "Giza Garapen Jasangarriaren esparruan tokiko garapenak oinarri izan behar dituen zutabeen eraikuntzan jartzen du arreta tokian tokiko kohesio eta ekimen komunitariotik abiatuta.

9 ACI Kooperatibe Nazioarteko Elkartea da.

10 5. Hezkuntza, prestakuntza eta informazioa: Kooperatibek heziketa eta prestakuntza eskaintzen diete beren kide, ordezkari hautatu, zuzendari eta langileei, beren kooperatiben garapenean eraginkortasunez lagundu ahal izan dezaten. Era berean, publiko orokorrari — bereziki gazteei eta iritzi-liderrei- lankidetzaren izaeraren eta onuren berri ematen diote.

6. Kooperatiben arteko lankidetza: Kooperatibak eraginkorragoak dira beren kideentzat, eta kooperatiben mugimendua indartzen dute, tokiko, nazioko, eskualdeko eta nazioarteko egiturekin lan eginez.

7. Komunitate-sentimendua: Kooperatibek beren komunitateen garapen jasangarria lortzeko lan egiten dute, kideek onartutako politiken bidez. 
Lehentasun horrek tokikoa-globalaren arteko erlazioak behetik gora artikulatzen direla esan nahi du, eskala globaletik eragiten duten erlazioen eta fluxuen ikuspegia galdu gabe. Horrela tokiko garapenaren ikuspuntuak ez du hainbeste bilatzen ekoizpenaren espezializazioa eta ekoizpen-kate globaletan zein lanaren nazioarteko banaketan txertatzea, baizik eta kohesioa eta ongizate soziala eta pertsonala helburu duen proiektu komunitario bat sustatzea» (Zurbano M. et al., 2014).

Helburu honekin bada, sektore ekonomiko guztiak aintzat hartu dira eta sustapen ekonomikoaren fase guztietan ESE-ak proposatzen dituen lanabes eta helburuak txertatu dira. Hau da, ESE-a sustatzeko estrategia eta ekintzak ez dira ez sektore ekonomiko zehatz batetara mugatu, ez eta Garapen Agentziek burutzen dituzten jarduera esparru bakan batzuetan jorratu, baizik eta esan bezala, lurraldeko behar guztiak asebetetzea helburu duen dibertsifikazio ekonomikoa bilatu du sustapen ekonomikorako burutzen diren jarduera guztietan ESE-ko printzipioak txertatzearen bidez. Horrela bada, esan dezakegu Beterri-Buruntzan sustatu den garapenerako estrategiaren helburua izan dela lurraldearen eta bizitzaren hedapena bermatuko duen matrize ekonomiko berri bat martxan jartzea. Horretarako jarraian sakonki azalduko diren ekintzailetza zerbitzua, inkubazio enpresarialerako espazioa, enpresen egonkortzea eta bideragarritasuna helburu duten proiektuak, laneratze eta gizarteratzerako espazio eta egiturak, eta hauen merkaturatzea ahalbidetzea bilatzen duen Erosketa Publiko Sozialki Arduratsurako politikak diseinatu, ezarri eta burutu dira.

\section{3. taula}

Beterri-Buruntza-ko Tokiko Garapenerako prozesuan ESE-a sustatzeko burutu diren proiektu eta eskaini diren zerbitzuak

\begin{tabular}{l|l}
\hline \multicolumn{1}{c|}{ Lan-sailak } & \multicolumn{1}{c}{ Proiektuak } \\
\hline EKINTAILETZA & $\begin{array}{l}\text { - KoopFabrika. } \\
\text { - Iturola. }\end{array}$ \\
\hline LANERATZEA & $\begin{array}{l}\text { - Beterri Errotuz. } \\
\text { - MaiteLan. }\end{array}$ \\
\hline 1GO SEKTOREA & - Bkm0. \\
\hline ENPRESEN ERALDAKETA & - Erakide. \\
\hline LURRALDEAREN ERALDAKETA & - Eraldaketa Nodoa. \\
\hline
\end{tabular}

Iturria. Geuk egina. 


\subsection{Ekintzailetza}

\subsubsection{KoOpFabrika}

Helburua:

KoopFabrika Olatukoop ${ }^{11}$, LANKI ${ }^{12}$, GEZKI ${ }^{13}$ eta Beterri Buruntza Udalak-ek Gipuzkoako Foru Aldundiaren diru laguntzekin diseinatu eta garatu duten ekintzailetza sozial eta kooperatiboa sustatzeko dispositiboa da. Zerbitzu honen bidez eskualdean sortzen diren enpresak Ekonomia Sozial Eraldatzailearen ereduaren baitan sortzea bilatu da.

Azalpena:

Ekimen hau 3 jarduera esparruren bidez osatzen da:

a) Formazioa eta tutorizazioa: Formazioa bi eremu nagusitan banatzen da. Batetik egungo eredu sozial, ekonomiko eta politikoaren kontraesanak bistarazi eta hauen gainean egun existitzen diren teoria eta proposamen praktikoen inguruko formazioa ematen da. Ikasleen politizazio kritikoa bultzatu eta hauen ekimen ekonomikoak aipatu ereduaren aurrean alternatibak eraikitzera bideratu daitezela bilatzen da, hau da, helburua da sustatzen diren ekimen ekonomiko hauek egungo eredu sozioekonomikoari alternatiba erreal eta materialak izatea. Bestetik, enpresa kooperatiboak modu bideragarrian kudeatzeko beharrezkoak diren teoria eta lanabes kutxa eskaintzen da, hala nola, enpresen kudeaketan irizpide feminista eta ekologikoak barneratu eta aplikatzeko beharrezkoak direnak. Tutorizazioa ere bi jarduera esparrutan banatzen da. Batetik, ekimen kooperatibo berri hauei eskaintzen zaien zerbitzua dugu. Tutore hauek Olatukoop sareko enpresetako langileak eta Beterri-Buruntza Udaleko teknikariak dira, eta 20 ordutako tutorizazio pertsonalizatua eskaintzen zaio ekimen berri bakoitzari. Tutorizazio saioetan formazioan esplikatu eta ezagutu diren lanabesak aplikatzen dira ekimen ekonomiko berrietan, esaterako bideragarritasun, komunikazio, kudeaketa... plana egiteko baliabideak ekimen berri hauen plan espezifikoak egiteko erabiliz enpresaren eratze prozesuan ber-

${ }^{11}$ https://olatukoop.eus/

12 LANKI Mondragon Unibertsitateko Ikerketa Kooperatiboen Institutua da. https://lanki. mondragon.edu

13 GEZKI Euskal Herriko Unibertsitateko Gizarte Ekonomia eta Zuzenbide Kooperatiboaren Instititua da. https://www.gezki.eus 
tan. Bestetik, tutoreak formatzeko eskaintzen den formazio saioak ditugu. Honen helburua da gero eta kooperatibista gehiago bihurtzea ekimen ekonomikoen sustapenerako aktibo. Formazio hauetan ekintzailetza prozesuan erabiltzen diren baliabide kutxako lanabesak erabiltzen ikasteaz gain, pertsonen eta taldeen kudeaketan ere gaitzea bilatzen da, ekimen ekonomiko berrien eremu tekniko eta humanoan ekarpena egiteko helburuz.

b) Saretzea: Ekimen ekonomiko berri hauek hasiera hasieratik lurraldean txertatu eta berau osatzen duten ehun ekonomiko, sozial eta politikoaren parte izatea bilatzen duen atala da. ESE-aren paradigmak enpresen arteko lehiakortasuna alde batera utzi eta eragile ekonomiko eta sozialen elkarlana eta konplementarietatea ditu helburu, beti ere lurraldearen dibertsifikazio produktiboa sustatu nahian. Hau horrela, ekintzailetza zerbitzutik sortzen diren ekimen berri hauei interkooperazioaren garrantzia azpimarratzen zaie bai modu teorikoan, formazio saiotan, zein modu praktikoan saretze ekimenen bidez.

Horrela saretze estrategia honek bi dimentsio nagusi ditu. Lehenengoa territoriala izango litzateke, eta horrela ekimen ekonomikoa kokatuko den lurraldean dauden eragile ekonomikoak, sozialak eta instituzionalak identifikatu eta beraiekin harremanetan jartzeko baliabideak eskaini, eta, ekintzak egiten dira. Bigarrena sektoriala da eta horretarako sektore berean edo balio kate berean kokatzen diren gainontzeko enpresen inguruko informazioa eta kontaktuak eskaintzen zaizkie. Modu honetan hornitzaile-bezero harremanak edukitzera eta elkarlanerako proiektuak diseinatzera bideratzen dira merkatuan lehiatzera baino.

c) Ikerketa eta ESE-aren dibulgazioa eta hedapena. Antolatzaileen artean bi unibertsitatek hartzen dute parte: EHU-ko GEZKI institutuak eta Mondragon Unibertsitateko LANKI institutuak, biak ala biak Ekonomia Sozial eta Eraldatzailearen inguruko formazio eta ikerketan adituak direnak.

ESE-a eraikitze prozesuan aurkitzen den proposamen sozioekonomiko bat izanik bere paradigma propioa eraikitzeko bidean aurkitzen da, eta horretarako teoria propioa eraiki eta teoria hau balidatuko duen adierazle sorta sortzeko beharrean dago. Horrela bada, eta bi unibertsitate hauetako kideek ESE-a definituko duten adierazle sistema bat eraikitzeko ikerketa lanaren inguruko argitalpenean dioten bezala "Lan honen inplikazio praktikoei dagokienean berriz, (...) adierazle sistemak bi zentzutako inplikazioak dituela esango genuke: teoria eraikitzen lagun dezakeen moduan lagundu nahi baitu gizarte eraldaketarako paradigma bat erakunde mailan 
gorpuzten, kudeaketa mailara jaisten, operatibizatzen» (Begiristain, Etxezarreta, Morandeira, 2020).

Emaitzak:

Beterri-Buruntza eskualdean 2014-2020 bitarte KoopFabrikaren 6 edizio burutu dira. 6 edizio hauetan 36 egitasmo ekonomiko sustatu dira, 14 kooperatiba; 10 elkarte; 7 autonomo; lan-sozietate mugatu 1; 3 sozietate-mugatu eta 2 ondasun-erkidego. Guztira 77 lanpostu berri sortzen lagundu da zerbitzu berri honen bidez.

Ekintzailetza zerbitzutik 104 pertsona pasa dira Beterri-Buruntza eskualdean.

\subsubsection{ITUROLA ELKARLAN SORGUNEA}

Helburua:

Iturola elkarlan sorgunea ekimen ekonomiko berrien inkubazio espazioa eskaintzen duen zerbitzu publikoa da. Zerbitzu honen helburua da KoopFabrikatik atera diren ekimen ekonomiko berriak merkatuaren presiotik at garatu eta egonkortzeko espazio bat eskaintzea, beti ere, ekonomia sozial eraldatzailearen balioetan sakondu eta praktikan jartzeko espazio bat eskainiz.

\section{Azalpena:}

Iturola elkarlan sorguneak berezitasun ugari ditu Gipuzkoan aurkitu ditzakegun gainontzeko inkubazio enpresarialerako espazioekin alderatuz. Berezitasun hauek ESE-aren printzipioak espazioaren funtzionamendura eramatean gauzatzen dira. Hauen artea nabarmenena espazioaren kudeaketa ereduan datza, kudeaketa eredu partekatua sustatzen baita Beterri-Buruntza Udalak-eko teknikarien eta bertan kokatuta dauden enpresetako kideen artean, ko-kudeaketa eredu parte hartzaile bat egikarituz. Beste berezitasun bat kokatuta dauden enpresek jasotzen dituzten baliabide eta zerbitzuak ordaintzerako orduan ageri dira, ordainketa hau ez baita dirutan bakarrik egiten, jasotzen diren baliabide eta zerbitzuak lan-ordutan ordaintzen dira, hau da, ekintzaile bakoitzak 6 ordu eskaini behar dizkio batetik espazioaren kudeaketari eta bestetik, lurraldeko eragile sozialekin harremana ehundu eta bere enpresak eskaintzen dituen produktu eta zerbitzuak aktibitate ekonomikoa ez duten eragile sozialei eskaintzeari. Ordainketa mota honen atzean bi ideia nagusi daude: lehenik eta behin ulertzen da inkubaziorako espazioa eta zerbitzuak komunitateak enpresei eskaintzen diz- 
kien baliabideak direla, eta beraz, ordainketa modu hau enpresa hauen balioa komunitatera itzultzeko modu bat dela aldarrikatzen da. Bigarrenik, ESE-aren bihotzean dagoen lurralderatze eta saretze estrategia dago. Ekimen ekonomiko hauek bere komunitateko ehun sozial eta politikoarekin artikulatzea bilatzen da lurraldeko beharrak asebete eta eredu ekonomiko autozentratu eta endogenoa sustatu nahian. Horrela bada, ekimen hauen balioa merkatuan gauzatzeaz haratago, bere komunitatearen beharrak asebetetzera bideratzen dira ere eta modu honetara ekonomiari zentzu eta norabide berri bat eskaintzea bilatzen da.

Azkeneko berezitasuna Iturola Elkarlan Sorgunean jorratzen diren praktika eta diskurtsoetan datza. Horrela bertan kokatuta dauden enpresen jarduera esparrua gainditu eta eredu ekonomiko eta sozial berri bat eraikitzeko agente aktibo bat da Iturola espazioa. Honen adibidea da 2019an zehar (pandemiarengatik eten zen ekimena) jorratu zen agenda soziala. Agenda honen bidez gure lurraldeetan aurkitu ditzakegun arazoak aztertu eta eremu sozioekonomikotik eman ahal zaizkien erantzunak aztertzen dira. Horrela, prozesu migratzaileak ezagutu eta paperik gabeko pertsonen egoerari ESE-aren bidez eskaini dakizkieken soluziobideak aztertu ziren; energia trantsizioa eta energia burujabetzak eskaintzen dizkigun aukerak aztertu ziren, etab...beti ere Iturolan parte hartzen duten enpresez gain herriko eta eskualdeko pertsonak eta eragileak gonbidatu zirelarik bai euren egoera aztertzera, bai planteatu daitezkeen soluzioen parte izatera.

Emaitzak:

Zerbitzu honen emaitzak bertatik ernaldu diren 29 ekimen ekonomikoak dira. Kuantitatiboki baino emaitza kualitatiboa da, enpresa hauek ESE-aren irizpideak barneratzeaz eta praktikan jartzeaz gain, eskualdeko tokiko garapenaren motor diren beste espazioen sortzaile eta partaide baitira. Bestetik, erreferentziazko espazio bat izatea lortu du eta jarduera ekonomikoaren inguruko narratiba berriak sortzeko eta hedatzeko gai izan da. Horrela, eskualdean sortzen diren ekimen ekonomiko berri askoren erreferentea izanik ekimen ekonomiko berri hauek ESE-aren printzipioetara hurbiltzea ahalbidetzen du.

\subsection{Laneratzealgizarteratzea}

Laneratze enpresa baten eta zaintzen kooperatiba integral baten sorkuntza. 


\section{Helburua:}

Beterri-Buruntza Udalak-en garapenerako estrategiaren baitan arreta berezia jarri zaio genero, jatorri edo pobrezia dela eta bazterkeria prozesuak bizi dituzten pertsona eta kolektiboen laneratze eta gizarteratzeari. Horretarako bi eremuetan, zaintzen sektorean eta ingurugiroaren kudeaketan zentratzen diren ekimen ekonomikoak sustatu dira. Batetik emakume migratu eta arrazializatuen eta bestetik pobrezia egoeran dauden pertsonen laneratzea eta gizarteratzea bilatzen duten ekimen ekonomikoak sustatu dira. Zehazki zaintzen sektorean irabazi asmorik gabeko eta ekimen sozialeko kooperatiba integral bat eta ingurugiroaren kudeaketarako laneratze enpresa bat sustatu dira ekimen publikoaren bidez.

\section{Azalpena:}

Proiektu hauek garatzeko eskualdea osatzen duten herrietako gizarte zerbitzuen sailak eta enplegu sailak bateratu dituen makro-sail berri bat sortu eta Enplegu-Soziala deritzon gobernantza markoa egituratu da. Sei herrietako bi sail hauek osatu duten gobernantza marko honek lanerako metodologia propio bat garatu du urteetan zehar. Batetik zerbitzu sozialen bidez bazterkeria egoeran dauden pertsonak identifikatzen dira, eta bestetik, enplegu departamentuen bidez pertsona hauen gaitze laboralerako ibilbide pertsonalizatuak diseinatu eta gauzatzen dira. Tokiko garapeneko teknikariek gobernantza esparru hau koordinatzeaz gain, lurraldean asetu gabe dauden behar sozial eta territorialak identifikatzen dituzte, zaintzaren sektorea eta ingurugiroaren kudeaketa kasu honetan, bai eta behar hauek asebeteko dituzten enpresen sorkuntza prozesua dinamizatu ere. Azkenik, identifikatutako behar sozial eta territorial hauen asebetetzea bermatuko duten kontratazio publikoak bideratzen dira, Erosketa Publiko Sozialki Arduratsuak ahalbideratzen dituen klausula sozial eta anbientalak ezarriz eta behar hauen estalketa ardura publikoaren baitan kokatuz. Modu honetan aipatu bi sektore hauetan esku-hartze publikoa sustatu da lehen aldiz.

\section{Emaitzak:}

Proiektu honetan lortu diren emaitza nagusiak laneratzea eta gizarteratzea helburu duten bi enpresen sorrera izan dira. Esan bezala Beterri Errotuz ${ }^{14}$ laneratze enpresa sortu da, 4 pertsonen laneratzea sustatu duena 2019 urtetik hona. Bestetik, emakume migratu eta arrazializa-

\footnotetext{
14 https://beterrierrotuz.eus/
} 
tuek sortu duten Maitelan ${ }^{15}$ Kooperatiba Integrala sustatu da. Pertsonen arreta eta zaintza lanak duintzea eta emakume migratuen egoera duintzea helburu duen kooperatiba hau 6 emakume langilek eta koordinatzaile batek osatzeaz gain, Iturola elkarlan sorgunean kokaturik dauden 20 enpresa inguru eta hainbat eragile sozial ere ekimen honen parte dira bazkide laguntzaile forman, pertsona hauen lana duintzeaz gain, zaintzen inguruan artikulatu den enpresa eta eragile multzo bat saretzea lortu delarik.

\subsection{Lehenengo sektorearen sustapena: Beterri KMO}

Helburua:

Beterri $\mathrm{Km} 0{ }^{16}$ eskualdeko lehenengo sektorea sustatu eta elikadura burujabetzan sakontzea bilatzen duen proiektua da. Finean, helburu nagusia Tokiko Elikadura Sistema bat eraikitzea izan da, hau da, elikaduraren sektoreko balio katean diharduten agente ezberdinen artikulazio estrategikoa eraikitzea.

\section{Azalpena:}

Proiektu honek bi finantzazio iturri nagusi izan ditu. Lehenengo Lanbideren eskutik etorri zen, 14.000 euro bideratu zituelarik enplegu berdea sustatzeko helburuarekin 2015ean. Diru laguntza honekin nekazal sektorearen lehenengo azterketa eta diagnostiko lanak egin ziren. 2017an berriz Eusko Jaurlaritzako Elikadura Industriaren Kalitateko zuzendaritzak 68.000 euro bideratu zituen, eta honekin aurretik egindako diagnostikotik irten zen ekintza plana gauzatu zen bi urteetan zehar.

Proiektu honetan bi eremu nagusitan egin da lan, eskaintzaren eremuan eta eskariaren eremuaren hain zuzen ere. Eskaintzaren eremuari dagokionez, hainbat ekimen egin dira eskualdeko ekoizpen gaitasuna handitu eta merkaturatzeko bide berriak bilatzeko helburuarekin. Batetik, eskualdean diharduten 9 ekoizle agroekologiko saretu dira eskaintza bateratu bat sortzeko helburuarekin, eta horretarako, produktu bakoitzaren prezioa adostu eta katalogo bat osatu dute. Bestetik, merkaturatzea erraztea bilatzen duen marka propio bat sortu da, BeterriKM0, zeinetan ekoizleek jarritako baldintzak bete behar diren bertan parte hartu ahal izateko. Ekoizpenaren sustapena egitea eta ekoizle berriak inkorporatzea errazteko lurren

15 https://maitelan.eus/

16 https://beterrikm0.eus/ 
bilaketa proiektuaren lan lerro estrategiko bat da. Landa garapenerako agentziarekin, hau da Behemendirekin elkarlanean lurrak bilatu, lurrak atondu eta ekoizleei bideratzeko lehiaketa publikoak egin dira.

\section{Emaitzak:}

Ekoizpen gaitasuna handitzearen esparruan 3 hektarea berri eta 3 ekoizle berri ezartzea lortu da. Formaziorako ekimenak ere egin dira, bai ekoizpenaren jasangarritasuna handitzeko zein etxaldeen eraginkortasuna handitzeko. Horrela bio-ongarrien ekoizpena egiten duen elkarte baten eskutik ekoizleek beraiek sortzen dituzten hondakinak bio-ongarri bihurtzeko formazio teorikoak eta saio praktikoak egin dira.

Eskariari dagokionez bi esparru handitan esku-hartu da, esparru publikoa eta esparru pribatua: Publikoari dagokionez esleipen publikoen bidez kudeatzen diren jantokietan klausula anbientalak ezarri dira eta ondorioz, Hernaniko kiroldegiko, igerilekuko eta zahar-etxeko sukaldeetan bertako produktua eskaintzera pasa dira. Bestetik ere, bi haur eskoletan eta lehen hezkuntzako ikastetxe batetako jangelan ere bertako produktua eskaintzera igaro dira. Eremu pribatuari dagokionez, eskualdeko 13 elikagai denda eta 5 jatetxe ere BeterriKm0 markan sartu dira eta bertako ekoizpenaren salmenta egiten dute. Edonola ere eremu pribatuan ez da sarea artikulatzea lortu, baserritarren eta jatetxe zein denden arteko harremanek hornitzaile profesionalen zerbitzuarekin lehiatzeko aukera gutxi baitute, eta ezinezkoa izan da bezero-hornitzaile sareak ehuntzea.

Azkenik aurrerago aurkeztuko dugun beste proiektu batetan parte hartzen duen Fagor enpresako jantokian ere bertako ekoizpena eskaintzera pasa dira.

\subsection{Enpresen eraldaketa: Erakide}

\section{Helburua:}

Beterri-Buruntzako garapen planaren beste ardatz estrategiko bat lurraldean kokatuta dauden enpresak Ekonomia Sozial Eraldatzailearen gakoetarantz trantsitatzeko prozesu eta baliabideak eskaintzea izan da. Horretarako 2015. urtetik Gipuzkoako Foru Aldundiaren diru laguntzaren eta Farapi aholkularitzaren laguntzarekin enpresen erantzukidetasun soziala neurtzen duen Erakide lanabesa sortu eta aplikatu da eskualdeko enpresetan, eta ondoren diagnostikoan identifikatutako ahulguneak garatzeko hobekuntza plan espezifikoak sustatu dira. 
Azalpena:

Erakide lanabesak enpresen erantzukidetasun sozialaren inguruko autodiagnostikoa modu kolektibo eta parte hartzailean egitea ahalbideratzen du, eta hau enpresan dauden ardura maila guztiak barnebiltzen dituen prozesu parte hartzaile baten bidez egiten da. Autodiagnostikoa egiterako orduan hiru eremu nagusi aztertzen dira: 1. hornitzaile/bezeroekiko harremanak; 2. pertsonak/langileak; 3. eremu soziala/lurraldea. Azterketa eremu hauek honako 3 dimentsioekin gurutzatzen dira: giza garapena; jasangarritasuna; parte hartzea/gardentasuna.

Lanabes honek eskaintzen duen balio erantsi nagusia da eraldaketarako tresna aplikatu bat dela, hau da, enpresak behin diagnostikoa egina duenean hobetu nahi duen eremu bat hautatzen du eta gai hortan espezializatuta dagoen aholkularitza baten bidez identifikatu diren arazoak konpondu eta enpresaren kudeaketa eredua eraldatzeko prozesu partekatu bat abiatzen da.

Beterri-Buruntzako garapen planean bi erabilera eman zaizkio Erakide tresnari. Batetik enpresen eraldaketa prozesuak sustatu eta hauek ESE-aren parametroetarantz gerturatzeko erabili da. Leku askotan aipatu den bezala, ekonomia sozialeko enpresek enpresa kapitalistekiko isomorfismo prozesu bat bizi ohi dute merkatuen baldintzen arabera leihakorrak izateko, eta ondorioz, ESE-aren printzipioengandik urrundu eta merkatu logiketan txertatzen joan ohi dira. Erakide tresnaren aplikazioaren bidez enpresa hauek beraien balio originalak berreskuratzeaz gain, aipatu hobekuntza prozesuen bidez balio hauek modu praktikoan aplikatzeko ikaskuntza prozesu bat egiten dute. Bestetik, eskualdearen eraldaketarako palanka gisa erabili da, hau da, lurraldea erantzunkidetasun sozialean espezializatzeko prozesua hauspotzea bilatu da. Lurralde espezializaziorako prozesu honek fase ezberdinak dauzka. Lehenik eta behin eskualdean kokatuta dauden hiru aholkularitza Erakide lanabesaren erabileran gaitu dira, horrela autodiagnostikoa egin nahi duten enpresa kopuru handiagoa diagnostikatzeko gaitasuna irabazi delarik. Horretaz gain, aholkularitza hauek erantzunkidetasunaren eta berrikuntza sozialaren sustapenerako dauzkaten jakintza eta baliabideak partekatu dituzte, diagnostikoa pasa ondoren egiten diren hobekuntza plan horien inguruko eskaintza handitu eta hau modu antolatu eta bateratuan eskaini ahal izateko. Hau da, enpresetan partehartzea, parekidetasuna, jasangarritasuna etab... handitzeko dauzkaten jakintza eta baliabideak partekatu dituzte beraien artean. Hurrengo pausua da Erakide pasako duten enpresen hautaketa modu planifikatu eta estrategikoan egitea. Urtean eskualdeko 10 enpresa inguru auto-diagnostikatzeko gaitasuna lortu denez, urtez-urte sektore ekonomikoaren, balio-katearen, forma juridikoaren edo kokatuta dauden parke enpresarial edo poligono industrialen arabera hau- 
tatzen dira diagnostikatuko diren enpresak. Modu honetara, urte gutxitan erantzukidetasuna lurraldean modu estrategikoan zabaldu nahi da, hau da forma juridiko jakin bat (kooperatibak hasiera batean), sektore ekonomiko zehatz bat, edo parke enpresarial edo poligono industrial bat erantzunkidetasunean gaitua eta aktiboa bihurtzea da helburua, lurraldearen eraldaketa sozioekonomikoa modu planifikatu eta estrategikoan sustatzea ahalbidetuko duelarik. Azkenik, erantzunkidetasunean sakontzen dauden diagnostikatutako enpresa hauen arteko elkarlanerako espazioak sortzen dira lurraldearen eraldaketarako espazio kolektiboak sortu eta hedatzeko helburuarekin.

Emaitzak:

2015 urtetik lortu diren emaitzak hurrengo hauek dira: lehenik eta behin Erakide lanabesa eskualdeko bi enpresen parte hartze aktiboarekin sortzea eta balidatzea lortu zen. Bigarren emaitza da eskualdeko 16 enpresek autodiagnostikoa eta hobekuntza plana eginda edukitzea da. Hirugarrena da Erakide pasa duten enpresa hauek lurraldearen eraldaketa helburu duten elkarlanerako espazio eta proiektuetan (Eraldaketa Nodoa eta Beterri Saretuz) engaiatu izana da. Laugarren emaitza da eskualdeko 3 aholkularitza Erakide lanabesa erabiltzeko gaitu eta beraien arteko lankidetza espazioa sortzea izan da. Eta azkena, oraindik prozesuan dagoena, Erakide modu estrategikoan lurraldea eraldatzeko erabiltzea da, zeinak azken helburu gisa duen lurraldea eranztunkidetasun sozialean espezializatzea eta garapen eredu berri batetarako oinarraik jarri eta ikaskuntza eta berrikuntza interaktiboko estrategia bateratua sortzea.

\subsection{Lurraldearen eraldaketa}

\subsubsection{ERALdaketa Nodoa}

\section{Helburua:}

Proiektu hau Erakide proiektuan parte hartu zuten enpresak eta beraien kabuz lurraldean eragina izatea bilatzen duten enpresak elkarlanerako espazio batetan elkartu eta eraldaketa ekonomikoa, soziala eta territoriala modu bateratuan sustatzea bilatu duen proiektua izan da. 2018 urtetik 2020 urteen artean garatu zen. 
Azalpena:

Eskualdean dauden 11 kooperatiba nagusienetakoek, industria, eskuhartze soziala, eta gizarte-aholkularitza sektoretakoak elkartu eta eraldaketarako agenda partekatu bat adostu eta ekintza plan kolektibo bat diseinatu eta gauzatu dute.

Proiektu honek Gipuzkoako Foru Aldundiaren diru-laguntza eduki du garatu den bi urteetan, 50.000 ingurukoak urtero, eta EHU-ko Hegoa institutuko ${ }^{17}$ ikerlari baten jarraipen eta aholkularitza akademikoa eduki ditu.

Prozesu horrek eskualdeko lurralde-gobernantzaren ardatzetako bat izatea bilatu du, eskualdeko garapen sozioekonomikorako planaren ibilbide nagusiak diseinatu ahal izatea helburu eduki duena. Alde horretatik, helburua izan da administrazio publikoak (Garapen Agentziak) eta lurraldeko enpresek garatzen dituzten ekintzak eta estrategiak koordinatzea eta eskualdearen eraldaketarako lurralde-agenda partekatua eraikitzea.

Elkarrekin lan egiteko bost dimentsio identifikatu dira, eta, dimentsio horiek zehazteko proiektuak eta prozesuak diseinatu dira. Dimentsio hauek gune honetan parte hartzen zuten enpresek eskaintzen dituzten gaitasun, behar eta interesen arabera eraiki dira: inklusibitatea (aniztasun funtzionala, generoa eta jatorri-aniztasuna); Jasangarritasuna (trantsizio energetikoa, elikadura-subiranotasuna eta mugikortasun iraunkorra) Tokiko garapen endogenoa (aipatu ditugun gainerako enpresa-guneekiko lotura ehuntzea, tokiko merkatu-soziala sortzea, Koopfabrikan parte hartzea); Kultura eta hizkuntzaren sustapena eta burujabetza teknologikoan sakontzea (beharrezkoak izango diren baliabide informatikoak software librean eraikiz).

Emaitzak:

Inklusibitatearen dimentsioan kokatzen den proiektuan 11 enpresa parte-hartzaileetatik $4 \mathrm{k}$ hartu dute parte. Hala, bakarrik dauden adingabe etorkinak gizarteratzeko eta laneratzeko sistema bat sortzeko helburua ezarri da. Horretarako, gazte horientzako harrera-zentroen kudeaketan aritzen den enpresa batek laneratze prozesuan sartzeko baldintzak betetzen dituzten pertsonak hautatu ditu, eta metal-mekanikan aritzen den beste enpresa batek konpromisoa hartu du gazte horietako bat har-

17 HEGOA Institutua: Euskal Herriko Unibertsitateko nazioarteko lankidetza eta garapenerari buruzko ikasketa institutua da. https://www.hegoa.ehu.eus/ 
tzeko, enpresa horren beharrei egokitutako prestakuntza-ibilbide bat egin dezan, praktikak egin ditzan eta kontratu egonkor bat egin eta kooperatibako bazkide izan dadin. Prozesu horretan parte hartzen duten beste bi aholkularitza-enpresek ere parte hartu dute, eta horiek arduratu dira harrera-prozesua errazteaz lanpostuan kulturartekotasun-prozesuak eginez. Bestalde, garapen-agentziako gizarte-enpleguko sailak hartzen du parte prozesu horretan, eta pertsonen ezaugarrien eta enpresen beharren arabera egokia den prestakuntza- eta lanbide-ibilbidea bilatzeaz eta trazatzeaz arduratzen da. Proiektu honek proiektu pilotua izan nahi izan du, esparru honetan parte hartzen duten beste enpresekin esperientzia sistematizatu eta orokortu ahal izateko.

Jasangarritasunaren dimentsioan ere abiatu da proiektu bat. Gorago aipatu bezala, partide den enpresa industrial bat, Usurbilen 500 langile dituen Fagor enpresak, bere jantokia Beterri $\mathrm{Km} 0$ proiektuan parte hartzen duten nekazarien produktuekin hasi da hornitzen.

Azkenik tokiko garapen endogenoaren dimentsioaren ondorioz ere eskualde mailako beste proiektu estrategiko (jarraian azalduko duguna) batetan bihurtu den interkooperaziorako espazio bat sortu zen. Zehazki Iturolan kokatuta zeuden enpresa txikiekin elkarlanerako espazio bat sortu zen eskualdean partaidetzan oinarritzen ziren enpresek osatutako ekosistema bat sortzeko helburuarekin, Beterri Saretuz izena hartu duen proiektua, hain zuzen ere.

Bukatzeko esan, Eraldaketa Nodoa deritzon proiektu honen garapena eten egin zela Beterri-Buruntzako garapen planaren aterkia zen udalen arteko lankidetza hitzarmena bertan behera gelditzearen ondorioz, nahiz eta bertan sortu diren harremanek eta proiektuetako batzuk (Beterri Saretuzek) beren kabuz aurrera jarraitu duten.

\subsubsection{BeterRi SARETUZ}

\section{Helburua:}

Beterri Saretuz proiektua orain arte aipatu diren proiektu eta espazio guztiak bateratu, saretu eta bertan parte hartzen duten partaideak eskualdeko beste eragile estrategikoekin, Lanbide Heziketako zentroekin, EHU-ko GEZKI institutuarekin eta administrazio publikoekin artikulatzea bilatzen du. Gipuzkoako Foru Aldundiak diruz lagundu du, eta, Iturolan eta Erakidetuz-en parte hartu duten enpresa talde batek sustatu eta dinamizatzen du Beterri-Buruntza Udalakeko teknikariarekin batera. 2019-an hasi zen proiektu honek partaidetzan oinarritzen diren enpresen, Lanbide Heziketa zentroak eta administrazio publikoa barne-biltzen dituen ekosistema bat sortzea du helburu nagusitzat, egungo koiuntura eko- 
nomikoaren baitan enpresen sustraitzea eta hauen binkulo territoriala bermatzeko lanabes eta prozesu gisa.

Azalpena:

Proiektu honetan erabiltzen den metodologia ikerketa-ekintza-partehartzaila da, zeinak, eragile ezberdinen arteko ikaskuntza prozesu partekatuak ahalbidetzea eta hedatzea bilatzen duen. Horrela, prozesuak 6 fase nagusi ditu, parte hartzearen inguruko azterketarekin hasi, eta ekosistema egituratu batekin amaitzea bilatuko duen prozesua izango da. Tartean beste praktika on batzuetatik ikasi eta zenbait eragilek beraien enpresetan eredu bat aplikatzeko aukera dute, fase batetik zein bestetik lortzen den ezagutza ekosistemara zabaltzeko ekimenak egin eta baliabideak sortuko direlarik $^{18}$.

Parte hartzearen inguruko hausnarketa eta praktika onak: Enpresetako parte hartze ereduen inguruko saioak eta informazio jasoketa. Parte hartze arlo ezberdinetan eredugarriak diren enpresen jarduna aztertzeko saio indibidualak egin dira, beraien metodologia eta praktiketatik ikasteko helburuz. Aztertzen diren partaidetza eremuak hurrengo hauek dira: jabetzan, kudeaketan, emaitzetan eta lurraldean. Partaidetza eremu hauek dira benetan beste enpresa, eta ondorioz beste ekonomia eredu batetaz hitz egitea ahalbidetzen dutenak.

Diagnostikoa eta gidaliburuen behin behineko garapena: enpresa eredugarrien saioetan jasotako informazioaren inguruko hausnarketa kolektiboa egin da. Ondoren, informazio horren sistematizazioa eta gidaliburuen eduki eta diseinua egin da. Horrela, ikasketa prozesu kolektibo bat jarri da martxan eta parte hartzearen arlo ezberdinak hobetzeko behin behineko gidaliburua sortu da.

Sentsibilizazioa/hedapena: parte hartzea sustatzeko eredu inspiragarriak jasotzen dituen gidaliburua eskualdera zabaltzeko ekimenak egin dira. Horretarako, mezua zabaltzeko formatu eta euskarri ezberdinak diseinatu eta garatu dira.

Ekosistema sortu: Prozesuan parte hartu duten eragile mota bakoitzak dituen beharrak eta gaitasunak artikulatuko dituen egitura bat gauzatzea bilatzen da. Modu honetan eskualdeko eragile sozioekonomikoak, hau da, administrazio publikoa, 4 Lanbide Heziketa zentro eta 20 enpresa inguru barne-bilduko dituen sare bat sortzeko prozesua abian da.

18 https://www.youtube.com/results?search_query=beterri+saretuz 
Emaitzak:

Proiektu honen emaitza nagusia eragile sozioekonomikoen artean sortu den subjektu kolektiboa da. Bestetik, enpresetan partaidetza sustatu eta sakontzeko ikasketa prozesua eman da, eta ikasketa hauek sistematizatu dituen gidaliburu bat sortu da. Azkenik, oraindik gauzatze bidean bada ere, lurraldearen eta egitura ekonomikoaren eraldaketa sustatu eta garapen eredu autozentratu, jasangarri eta demokratiko baten agente bihurtzea bilatzen duen ekosistema territoriala gauzatzen ari da, prozesuaren baitan erabiketzeke dagoelarik ekosistema honek forma juridikoa (elkartea) hartuko duen edo ez.

\section{Beterri-buruntza-ko ESETS-a}

Ekonomia Sozial Eraldatzaileko Tokiko Sistema bat osatzean aurreratu den ala ez zehazteko arestian Tokiko Ekoizpen Sistemak definitzeko identifikatu ditugun ezaugarriak azaldu ditugun ekimenekin eta Arcos eta Morandeirak (2020) proposatutako ESETS-en ezaugarriekin bateratzen saiatuko gara.

Horrela, ariketa honen bidez saiatuko gara ikusten ea maila teoriko batean definitu diren Tokiko Ekoizpen Sistemen eta ESETS-en ezaugarriak maila praktiko batean gauzatu diren Beterri-Buruntzan egin den saiakeran. 
TOKIKO GARAPENA ETA EKONOMIA SOZIAL ERALDATZAILEKO TOKIKO SISTEMAK

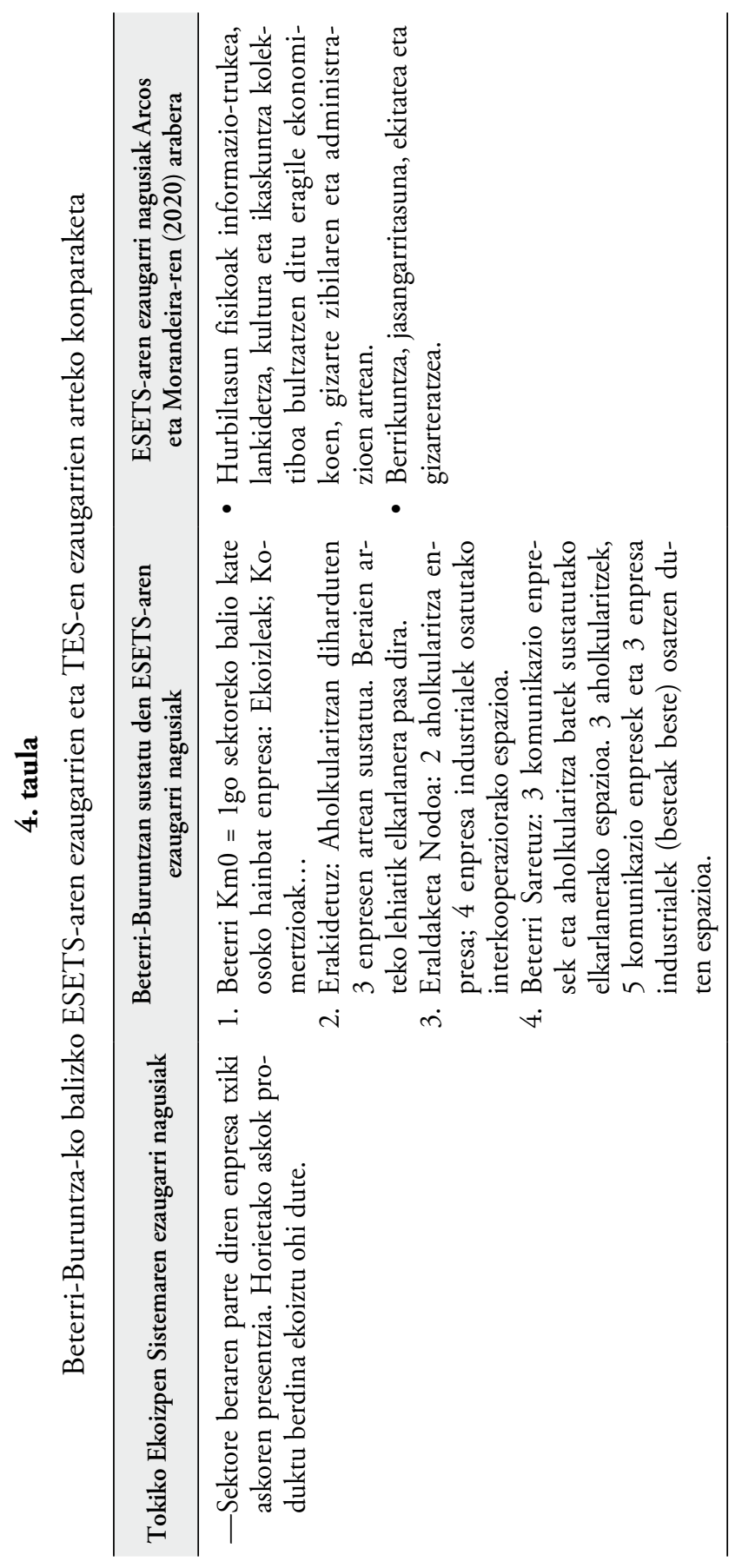




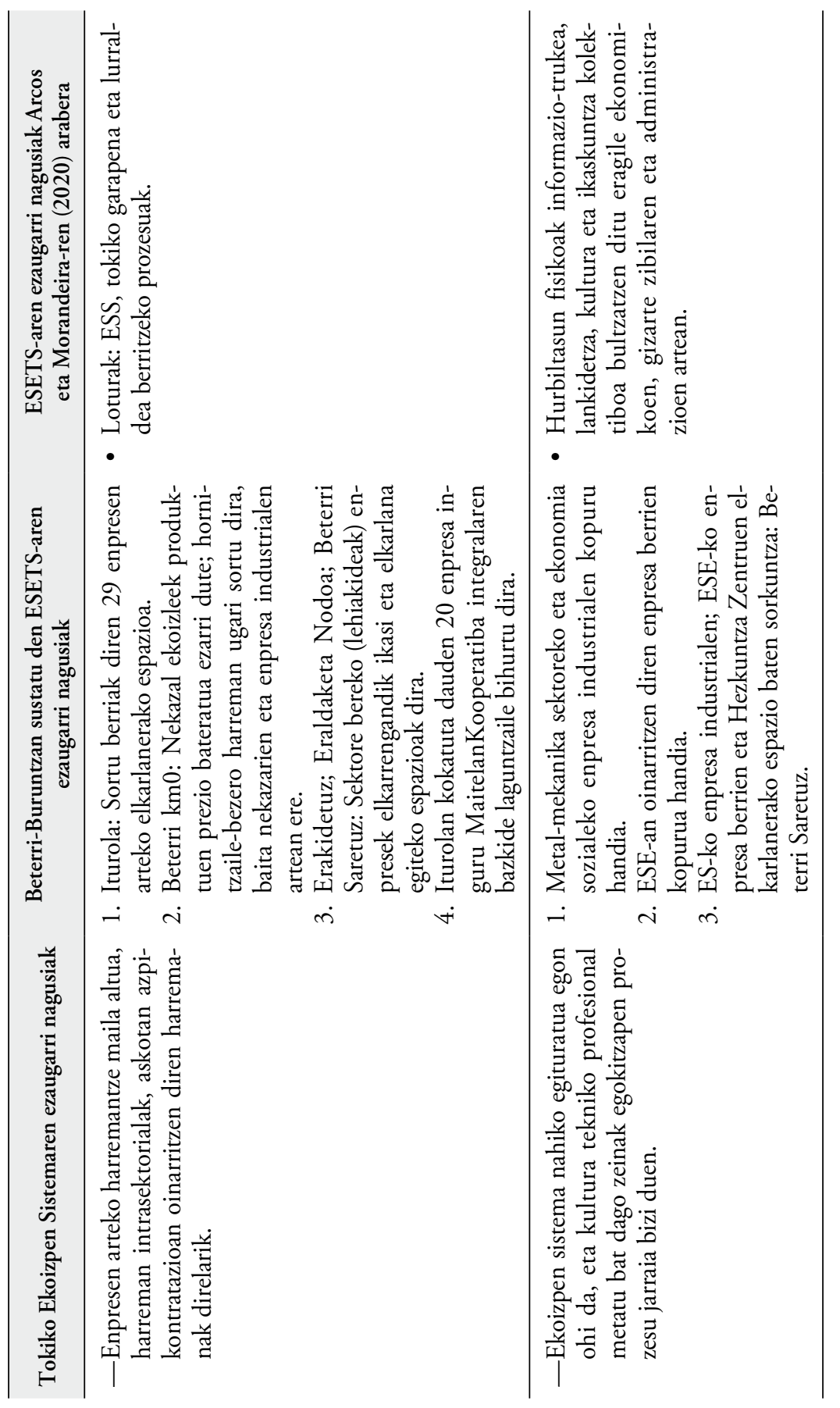



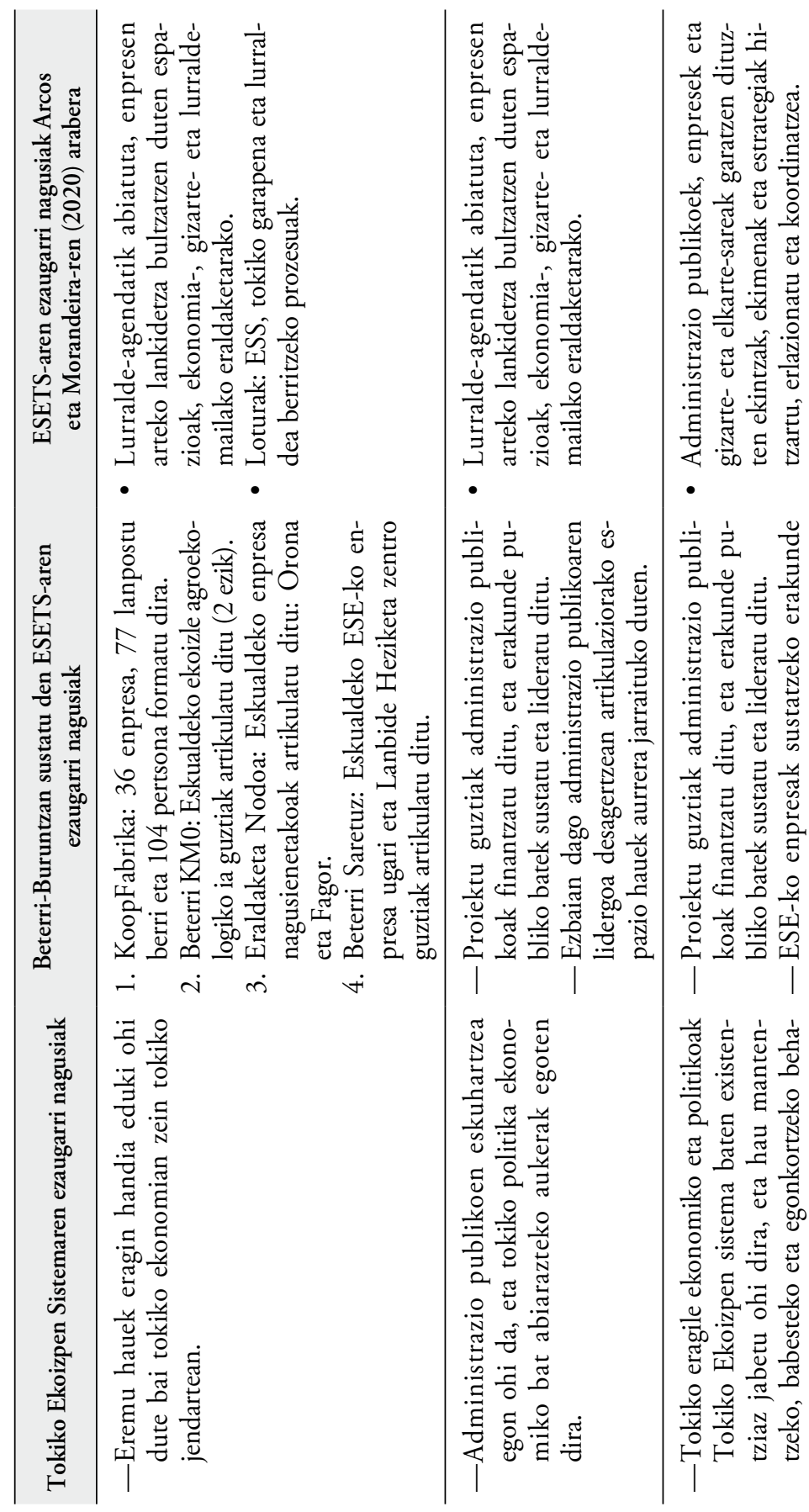

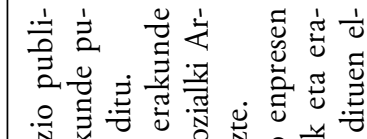

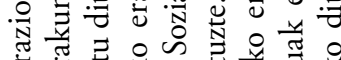

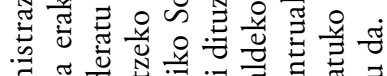

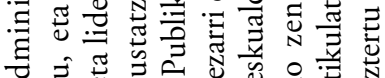

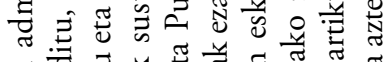

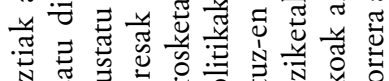

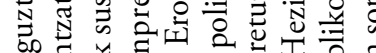
ठ0

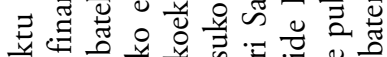

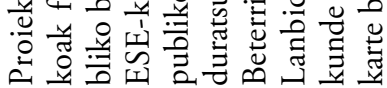

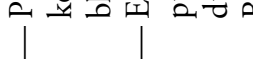

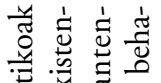

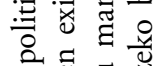

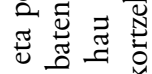

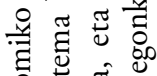

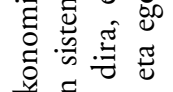
원 긍 온

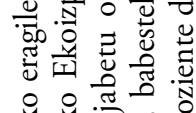

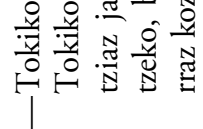




\section{Ondorioak eta eztabaida}

Beterri-Buruntza eskualdean egin den Tokiko Garapenerako saiakera hau baloratzerako orduan bi dimentsiotan fijatzeko beharra begiztatzen da, batetik, tokiko garapenaren sustapenerako eredu alternatiboa gauzatzea lortu den ala ez ebatzi behar da. Bestetik, tokiko garapenerako eredu honek ESETS-a egikaritzea lortu duen ala ez ondorioztatu behar da.

Lehenengo dimentsioaren balorazioari dagokionez, tokiko garapenaren sustapenerako eredu alternatibo bat gauzatu dela ondorioztatu daitekela uste dugu honako 4 arrazoi nagusiengatik:

1. Proiektu eta zerbitzu zehatzei dagokionez, tokiko garapenerako eredu hegemonikoa sustatzen duten garapen agentziek eskaintzen dituzten zerbitzu guztiak eskaini dira baino kasu honetan Ekonomia Sozial Eraldatzailea sustatzeko helburuarekin. Ikusi dugun bezala ekintzailetza zerbitzua; enpresen inkubaziorako espazio eta zerbitzua, enpresen arteko saretzea, gizarteratze eta laneratzerako ekimenak eta sektore estrategikoen sustapena egin da.

2. Diskurtso eta relatoari dagokionez, Ekonomia Sozial Eraldatzailearen diskurtso, printzipio eta praktikak propiotzat hartu dira eredu hegemonikoaren diskurtso, printzipio eta praktiken gainetik. Horrela lehiakortasuna sustatu ordez elkarlana eta kooperazioa aldarrikatu da; espezializazio produktiboa baino dibertsifikazioaren alde egin da, nazioartekotzea bilatu ordez askitasuna eta burujabetza landu dira; ekonomia produktiboan bakarrik zentratu ordez ekonomia erreproduktiboa eta feminista aintzat hartu eta praktikara eraman dira, eta produktibitatea eta eraginkortasunaren ordez langileen partehartze multidimentsionala ardatz nagusitzat hartu da.

3. Gobernantzari dagokionez bi elementu azpimarratu daitezke: 1. Gipuzkoako ikur den gobernantza multieskalarraren parte aktibo izan da. Horrela gainontzeko garapen agentziek bezala Gipuzkoa Sarean prozesuan hartu da parte, eta, hemen aurkeztu diren proiektuek bai Gipuzkoako Foru Aldundiaren sustapen ekonomikorako sailaren zein Eusko Jaurlaritzaren Lanbideren finantzaketa jaso dute. Hau da gobernantza eredu horren baitan aitortuak eta baloratuak izan diren proiektu bideragarriak aurkeztu eta gauzatu dira. Bestetik, eskualde mailako gobernantza eredu propio bat eraiki da, hau da, eskualdeko ESE-ko agenteekin batera eraldaketa territoriala bilatu duen ko-gobernantza eredua gauzatu da (Villalba-Eguiluz et al., 2020).

4. Burutu diren proiektuek eta eskaini diren zerbitzuek inpaktu erreal eta neurgarria eduki dute bai egitura ekonomikoan zein lu- 
rraldean. Enpresa eta lanpostu berriei dagokionez Ekonomia Sozial Eraldatzailearen baitan diharduten 36 enpresa eta 77 lanpostu berri sortu dira, eta, 104 ekintzaile artatu dira. Inkubazio zerbitzuan 29 enpresa eta 100 pertsonatik gora lagundu dira. Laneratze eta gizarteratzeari dagokionez 4 langiletako laneratze enpresa bat eta 6 zaintzailek osatutako kooperatiba integral bat sustatu dira. 1 go sektoreari dagokionez batetik, nekazaritzarako 3 hektarea berri bideratu dira eta 3 lanpostu berri sortu dira, bestetik, Hernaniko zahar egoitza, Usurbileko Fagor enpresa eta 2 haur eskola eta ikastola batetako jantokiak bertako ekoizpenarekin hornituak izatera pasa dira. Enpresen erantzunkidetasuna eta eraldaketarako prozesutik 16 enpresa igaro dira eta egun eskualdeko 3 aholkularitzen arteko interkooperazio proiektu bat martxan dago. Proiektu honen bidez erantzunkidetasunaren inguruko autodiagnostikorako lanabesa eskualdeko enpresetan modu estrategikoan pasa, eta, erantzunkidetasun sozialean oinarrituko den tokiko garapenerako politikak eta proiektuak sortzea bilatzen da. Enpresen artikulazioa eta saretzea helburu duten bi proiektuetan 31 enpresek eta 4 lanbide heziketako zentroek hartu dute parte. Azkenik, Beterri Saretuz proiektuak aurrera darrai bere kabuz, eta 2021 eko ekainean sare honen etorkizunaren inguruko gogoeta saio bat burutu dute enpresak, lanbide zentroak eta administrazio publikoa barne-bilduko dituen elkarte bat sortzeko aukera aztertzeko.

Tokiko garapenaren sustapenerako eredu alternatibo bat sortu dela baieztatu dugun arren, Beterri-Buruntzan burutu den saiakera honen behin-behinekotasunak ekartzen dizkigun ikasgaiak ere lehen lerrora ekarri behar dira. Eredua sortu den arren eredu hau ez da egonkortu eta ez du lortu irauteko eta nagusitzeko ezinbestekoa den aitortza politiko, ekonomiko eta soziala. Saiakera hau 7 urtetan zehar garatu da, zehazki tokiko garapenerako egitura formalik egon ez den bitartean, baino eskualdeko mankomunitatea sortzearekin batera proiektuetako asko bertan behera gelditu dira. Honek saiakera honen izateko aukera-baldintzen inguruko gogoeta egitera behartzen gaitu. Zentzu honetan esan behar da eredu hau posible izan dela tokiko garapenerako egitura formalik ez egoteak ekarri duen zuzendaritza politiko argi baten gabeziarengatik, zeinak aukera eskaini duen berrikuntza eta experimentazioa sustatu eta prozesu heterodoxo bat abian jartzeko. Zuzendaritza politiko argirik ez egoteak eskualdeko eragileen artean osatutako eta adostutako estrategia territorialik ez egotea ekarri du, eta honek teknikarien sinesgarritasun eta legitimitate falta handia eragin du eskualdeko enpresa eta eragile sozioekonomiko nagusienen aurrean. Hau dela eta Beterri-Buruntza eskualdean egin den saiakerak ez du lortu gaine- 
rako eskualdeetan garapen agentziek eta tokiko garapenerako estrategiek duten, eta ezinbestekoa den aitortza; legitimitatea eta autoritatea, eskualdeko teknikari batzuen eta ESE-ko eragile batzuen boluntarismoan eduki duelarik oinarririk nagusiena.

Bigarren dimentsioaren balorazioari dagokionez ESETS bat sustazea lortu den eta balizko ESETS horrek eredu sozioekonomiko demokratikoagoak, iraunkorragoak eta bidezkoagoak eraikitzeko baldintzak eskaintzen dizkigun ebaztea dagokigu.

4. taulan ikusi daitekenez, Tokiko Ekoizpen Sistemen ezaugarriak, Beterri-Buruntzan sustatu den eredua eta ESETS-aren ezaugarriak alderatzerakoan korrelazioa aurkitu da. Zentzu honetan uste dugu Beterri-Buruntzan sustatu den ereduak TES-en eta ESETS-en oinarri teorikoak modu materialean gauzatu dituela, hau da Tokiko Ekoizpen Sistemen ezaugarriak Ekonomia Sozial Eraldatzailearen sustapenerako berrartikulatu dituela, beti ere, ESETS-ak definitzen dituzten ezaugarri teorikoak modu praktikoan gauzatuz eta honek markatzen duen ipar estrategiko eta politikoa jarraituz.

Horrenbestez uste dugu tokiko garapen hegemonikoan hain sustatua izan den TES-aren kontzeptua ESE-an oinarritzen den tokiko sistema bat, eta ondorioz, garapen eredu alternatibo bat aktibatzeko baliagarria izan daitekela, noiz eta, ESETS-aren oinarri teorikoek markatzen duten iparra galtzen ez bada, eta, eraldaketa soziala, ekonomikoa eta territoriala helburutzat mantentzen bada.

Beterri-Buruntzan bultzatu den saiakerak bada, ESETS-aren oinarri teorikoak modu praktikoan gauzatzea lortu badu ere, uste dugu gauzapen hau oso hastapeneko maila batean bakarrik eman dela. Hastapeneko maila prefiguratibo honetan gelditzearen arrazoiak ugariak dira:

1. Tenporala: Saiakera hau 7 urtetan zehar besterik ez da eman. 7 urte oso denbora gutxi da berregituraketa ekonomiko bat lortzeko, eta are eta gehiago hegemonikoak ez diren teoria eta praktiketan oinarritzen bada.

2. Kuantitatiboa: Gipuzkoak ESE-ko erakundeen dentsitate handia duen arren, gogoan eduki behar da eskualdean enpleguaren \%12 eta BPG-aren \%11.9 ${ }^{19}$ dagokiola gizarte ekonomiari, eta beraz, ekonomiaren zati txiki baten parte batetaz bakarrik ari garela.

3. Egiturazkoa: Ingurumariari erreparatzen badiogu errez begiztatzen zaigu lehiakortasuna oinarri eta mugagabeko hazkundea helburu dituen egitura kapitalistaren zentroan kokatuta egoteak oso modu determinantean eragiten diela sektore guztietako eragile ekonomi-

19 https://oves-geeb.eus/es/sabias-que-7/ 
koei. Horrela bada, ESETS-ak Ekonomia Sozial Eraldatzailearen sustapena egitea helburu duen bitartean, ESETS-a osatzen duten eragileek merkatu kapitalista eta lehiakorrean bizirauteko beharra daukate, eta beraz bigarren mailako helburua da eragileontzat eskualdeko ESETS-aren eraikuntza. Horrenbestez egiturazko arrazoi honek ESETS-ek daukaten erronka argi bat erakusten digute: ESETS-a bera izatea bai enpresak biziraun ahal izateko eta bai biztanleek beraien behar sozioekonomikoak asebetetzeko baliabiderik nagusiena.

4. Politikoa: Hemen planteatu dugun definizioaren arabera ESETS-a lurralde zehatz batean ESE-aren sustapen eta hedatze prozesua modu esplizitu eta intentzional batean gauzatuko duen gobernantza eredu publiko-kooperatibo-komunitarioa eta hemendik eratortzen diren proiektu eta zerbitzuen multzoa direla esan dugu. Hau horrela izanik, eta gobernantza eredu hau maila batean martxan jartzea lortu bada ere, gobernantza eredu honen erpinetako bi ez dira guztiz garatu eta ez dute beharko luketen rola bete. Erpin politikoa eta erpin komunitarioa dira maila batean edo bestean presente egon arren oso modu testimonialean egon direnak. Bereziki, eta lehen esan bezala erpin politikoa izan da hutsune handiena utzi duena. Arestian esan bezala garapen prozesuaren zuzendaritza politiko argi bat ez egoteak benetako apustu politiko argia ekidin du, eta ondorioz ESETS honen eragiteko gaitasuna ez da izan litekeena bezain eraginkorra.

Horrenbestez, maila batean ESETS-a egituratzea lortu dela esan badaiteke ere, ESETS hau oso urruti dago oraindik eredu sozioekonomiko demokratikoagoa, iraunkorragoa eta bidezkoagoa gauzatzetik. Edonola ere eredu hori eraikitzeko ezinbestekoak izango diren planoen zirriborroak marraztuak eta zereginak zerrendatuta utzi direla uste dugu.

Horrela bada, administrazio publikoak orain arte eduki duen lidergotza bertan-behera gelditzen ari den honetan, ikusteke eta disputatzeke gelditzen da sortu den ESETS-ak heldutasun-maila nahikoa edukiko duen lurraldearen eredu sozioekonomikoa eraldatu eta ESE-ko ekosistema autonomo bat ernaldu ahal izateko.

\section{Bibliografia}

Alburquerque, Francisco (2004): El enfoque del desarrollo económico local. Cuaderno de capacitación No. 1. Serie: Desarrollo Económico Local y Empleabilidad Programa AREA - OIT en Argentina - Italia Lavoro. Buenos Aires, Organización Internacional del Trabajo 2004. 
Aranguren, Mari Jose, Morgan, Karl \& Wilson, James (2016): Implementar la RIS3. El caso del País Vasco. Cuadernos Orkestra. Orkestra Instituto Vasco de Competitividad. Fundación Deusto.

Arcos, Asier \& Morandeira, Jon (2020): Ecosistemas locales de economía social y solidaria en la Comunidad Autonoma Vasca. Una aproximación desde la entidades. RIESISE. Revista Iberoamericana de Economía Solidaria e Innovación Socioecológica. Vol. 3 (2020), pp. 37-59 • http://dx.doi.org/10.33776/riesise. v3i0.4544

Begiristain, Miren, Etxezarreta, Enekoitz \& Moraindeira, Jon (2021): Mozkin asmoagatik ez bada, zein da ba asmoa? Ekintzailetza sozial kooperatiborako adierazle sistema baten proposamena. Ekonomiaz, n. ${ }^{\circ}$ 99, $1 .{ }^{\text {er }}$ semestre, 2021, pp. 271-293.

Bengoetxea Aitor (2015): El empleo en las cooperativas de trabajo asociado: ¿Derecho al trabajo o factor productivo? Lan harremanak: Revista de relaciones laborales, n. ${ }^{\circ}$ 32. https://doi.org/10.1387/lan-harremanak.15393

Calvo Palomares, R. \& González Cardona, J. (2011): La creación de empresas de economía social en el modelo de desarrollo local: reflexiones sobre la divergencia actual del caso valenciano. REVESCO. Revista De Estudios Cooperativos, 104, 7-37. https://doi.org/10.5209/rev_REVE.2011.v104.1

Etxezarreta, Enekoitz, Etxezarreta, Aiztiber, Zurbano, Mikel \& Estensoro, Miren (2015): Innovación Social, Políticas Públicas y Economía Social y Solidaria. Papeles de Economía Solidaria. REAS Euskadi.

Europar Komisioa (2011): Agenda Territorial Europea 2020. Hacia una Europa integradora, y sostenible inteligente de regiones diversas. European Comission, Brussels.

Fernández Ortiz de Zárate, Gonzalo (2016): Alternativas para desmantelar el poder corporativo: Recomendaciones para gobiernos, movimientos y ciudadanía. Cuadernos de Trabajo Hegoa, 1-52.

Gainza, Xabier \& Unceta, Koldo (2011): Los factores socio-territoriales y su incidencia en las estrategias locales de desarrollo: el caso de las agencias de desarrollo local en el País Vasco. Revista de Estudios Regionales, 92:113-143.

IICA (2013): Sistemas Agroalimentarios Localizados (SIAL), una nueva visión de gestión territorial en América Latina: experiencias en territorios de Argentina, Costa Rica, Ecuador y México / IICA, CIRAD-México.

Karlsen, James \& Larrea, Miren (2015): Desarrollo territorial investigación acción: Innovación a través del diálogo. Orkestra-Institu Vasco de Competitividad. Fundación Deusto.

Larrea, Miren (1999): Competitividad y empleo en los sistemas productivos locales. Ekonomiaz: Revista vasca de economía, n. ${ }^{\circ} 44$, 1999, 144-173.

Larrea, Miren (2002): Clusters y territorio: retos del desarrollo local en la Comunidad Autónoma del País Vasco. Ekonomiaz: Revista vasca de economía, n. ${ }^{\circ} 53,2020,138-159$. 
Mohan, Giles \& Stokke, Kristian (2000): Participatory development and empowerment: The dangers of localism, Third World Quarterly, 21:2, pp. 247268.

Perez Orozco, Amaia (2014): Subversión feminista de la economía. Madrid. Traficantes de sueños.

Rendón, Jaime Alberto \& Forero, Jesus David (2014): Sistemas productivos locales: estrategias empresariales para el desarrollo. Semestre Económico, volumen 17, No. 35, pp. 75-94.

Villalba-Eguiluz, Unai, Egia-Olaizola, Andoni \& Pérez de Mendiguren, Juan Carlos (2020): «Convergences between the Social and Solidarity Economy and Sustainable Development Goals: Case Study in the Basque Country,» Sustainability, MDPI, Open Access Journal, vol. 12(13), pages 1-19, July.

Villalva-Eguiluz, Unai, Pérez de Mendiguren, Juan Carlos \& Egia, Andoni. (2019): Sistemas Locales de Economía Social y Solidaria (SLESS) Innovación, sostenibilidad, equidad e inclusión. Conferencia Internacional de UNTFSSE, 2019.

Vazquez-Barquero, Antonio (2000): Desarrollo Endógeno y Globalizazión. Revista eure (Vol. XXVI, n. ${ }^{\circ}$ 79), pp. 47-65, Santiago de Chile, diciembre de 2000.

Zurbano, Mikel Bidaurratzaga, Eduardo \& Gainza, Xabier (2014): Interrelación local-global en los procesos de Desarrollo Humano Local. Hegoa. 